\title{
EUROZONE PRICES: A TALE OF CONVERGENCE AND DIVERGENCE
}

2020

\section{BANCODEESPAÑA}

Eurosistema

Documentos de Trabajo

N. ${ }^{\circ} 2010$

Alfredo García-Hiernaux, María T. González-Pérez and David E. Guerrero 
EUROZONE PRICES: A TALE OF CONVERGENCE

AND DIVERGENCE ${ }^{(*)}$

Alfredo García-Hiernaux ${ }^{(* *)}$

DANAE AND ICAE

María T. González-Pérez ${ }^{(* *)}$

BANCO DE ESPAÑA

David E. Guerrero ${ }^{(* * *)}$

CUNEF

(*) For insightful suggestions and comments we thank Adrian van Rixtel, Ricardo Gimeno, Luciano Campos, Jeremy Staum, Luis Julián Álvarez González and Mirko Wiederholt, and seminar participants at the 2014 Midwest Econometrics Group Meeting and Banco Central del Uruguay, 2015. Alfredo García-Hiernaux acknowledges support from the grant UCM-Santander PR75/18-21570.

(**) DANAE and ICAE, Universidad Complutense de Madrid, 28223 Madrid, Spain.

${ }^{(* \star *)}$ Corresponding author: mgonzalezperez@bde.es, Banco de España, 28014 Madrid, Spain.

${ }^{\star \star \star \star *}$ CUNEF (Colegio Universitario de Estudios Financieros), 28024 Madrid, Spain.

Documentos de Trabajo. N. ${ }^{\circ} 2010$

2020 
The Working Paper Series seeks to disseminate original research in economics and finance. All papers have been anonymously refereed. By publishing these papers, the Banco de España aims to contribute to economic analysis and, in particular, to knowledge of the Spanish economy and its international environment.

The opinions and analyses in the Working Paper Series are the responsibility of the authors and, therefore, do not necessarily coincide with those of the Banco de España or the Eurosystem.

The Banco de España disseminates its main reports and most of its publications via the Internet at the following website: http://www.bde.es.

Reproduction for educational and non-commercial purposes is permitted provided that the source is acknowledged.

(C) BANCO DE ESPAÑA, Madrid, 2020

ISSN: 1579-8666 (on line) 


\section{Abstract}

This article provides a methodology to test absolute and relative price convergence (in mean and variance) based on a model of relative prices that includes a transition path, and offers a way to measure the speed of price convergence across countries. By applying this test to the European Monetary Union (EMU) price indices from 2001 to 2011, we find empirical evidence of different price level patterns and the lack of price level convergence in the long run for most countries. In terms of the price gap between countries, only when we compare the German with French and Italian prices, we do get zero-gap (absolute) price level convergence. A few other countries report relative price level convergence. These results underscore the existence of a "convergence cost" that EMU countries with lower price levels paid and that does not tend toward zero in the long-term in the absence of convergence. This finding might be of particular interest to European monetary policymakers as it implies that implemented monetary policy does not affect (benefit/harm) all EMU members equally. Monitoring the relative and absolute price level convergence is advised to understand the monetary policy efficiency in the long run.

Keywords: price level convergence, mean convergence, variance convergence, inflation, monetary union, monetary policy.

JEL classification: C22, C32, N70, E3, E4, E5. 


\section{Resumen}

Este artículo describe una metodología que permite contrastar la convergencia absoluta y relativa del nivel general de precios (en media y varianza), basada en un modelo de precios relativos que incluye un proceso de transición y permite medir la velocidad de convergencia de precios entre un conjunto de países o regiones. Aplicamos esta metodología considerando el nivel de precios de los países miembros de la Unión Monetaria desde 2001 hasta 2011 y encontramos distintos patrones de comportamiento para las series precios de los países miembros, así como la falta de convergencia en el largo plazo para la mayoría de estos. Así, atendiendo al diferencial de precios entre países, solo encontramos convergencia absoluta de precios, con diferencial igual a cero, cuando comparamos el nivel de precios alemán con el francés y el italiano. Por otra parte, solo un subconjunto de países muestra convergencia relativa, con un diferencial de precios constante distinto de cero. Estos resultados revelan la existencia de un "coste de convergencia» pagado por los países con menor nivel de precios, que no tiende a cero en el largo plazo cuando no existe convergencia. Ello resultaría de interés para los responsables de la política monetaria, ya que evidencia el efecto desigual de dicha política en los países miembros de la EMU. Se recomienda la previsión y seguimiento de la convergencia (relativa y absoluta) del nivel de precios en la zona euro para entender la eficiencia de la política monetaria a largo plazo.

Palabras clave: convergencia de precios, convergencia en media, convergencia en varianza, inflación, unión monetaria, política monetaria.

Códigos JEL: C22, C32, N70, E3, E4, E5. 


\section{Introduction}

The European Monetary Union (EMU) faces a significant challenge, the economic integration of the countries within the EMU area. Significant players in the economic and financial spheres warn about the non-negligible risk of EMU disintegration (see, for instance, Alvarez and Dixit, 2014; Draghi, 2014) in the absence of a clear path to achieve it, and conventional wisdom demands a more coordinated fiscal policy as a formula to achieve more effective economic (and financial) integration. Oliver Blanchard claimed at the 2019 ECB Forum on Central Banking, that it is not only "the inadequacy of the fiscal policy framework" that contributes to weakening the Euro macro policy architecture, but also "the lack of adjustment of relative prices" in the Euro area. ${ }^{1}$ This paper contributes to this debate offering an econometric framework to test and estimate the price convergence process using a model of relative price levels that includes a transition path. ${ }^{2}$ Estimating the price convergence process carried out in the EMU area will help to understand and predict the effects of monetary policy on the EMU economies and to enhance the EMU's institutional stability. This paper provides: (i) a test to determine the (absolute and relative) price convergence in mean and variance across countries, and (ii) a methodology that allows researchers to estimate the speed of price convergence in a common area when it occurs. Empirical results from our analysis confirm that the EMU countries' price levels follow different patterns that do not converge in the long run, in a relative sense. ${ }^{3}$

Our results highlight the significant difficulties in the implementation of a coordinated monetary policy in the EMU when there is a single inflation target and multiple patterns of price levels, i.e, different long-run inflation rates. Wide and persistent inflation gaps could increase long-run real interest rate differentials and exacerbate the inflation-gap problem, affecting the cost of credit and low-productivity firms/countries in a vicious circle. The price integration problem might be also significantly related to segmented financial markets in the EMU, resulting from a monetary policy that might have underestimated the additional challenges implied by the current international monetary system. ${ }^{4}$

Many inequalities emerge from the existence of different long-run inflation rates in the EMU. Higher inflation leads to lower real interest rates and, as Liu et al. (2019) highlight, very low long-term interest rates increase market concentration and enhance "a widening productivity gap", as the interest rate approaches zero. While prior studies agree on the effect of persistent inflation gaps on the effectiveness of monetary policy in maintaining price stability, there is no conclusion on the effects of a single common inflation target on the EMU's economy with different price levels and persistent inflation differentials. This paper suggests that an optimal policy framework of the ECB should not only focus on a single common inflation target in the short run, as in one-size-fits-all but should also follow and include a criterion for the price level convergence pattern in the area in the long run, at least in a relative sense. Otherwise, the lack of price level convergence may widen the real interest rate

\footnotetext{
${ }^{1}$ See the full speech at ECB webpage.

${ }^{2}$ This paper focuses on estimate the price convergence process, rather than on the factors that enhance it. There is broad research on price convergence determinants included, but not restricted to, the BalassaSamuelson model. See Berka et al. (2018) for a recent literature revision.

${ }^{3}$ Usually, relative Purchasing Power Parity (PPP) refers to inflation convergence, and absolute PPP refers to absolute price level convergence. For instance, relative PPP implies a common trend in price levels.

${ }^{4}$ Not only a new order in the sense of a turbulent transition to a new multipolar monetary system, with the emerging Euro and the Renminbi currencies, but also because of the appearance of new digital currencies and financial technology; see Caballero et al. (2015) and Farhi and Maggiori (2017).
} 
and productivity gaps across countries. This way, the ECB might contribute to reducing the economic heterogeneities represented by different trends in the EMU price levels by adding a convergence policy. This paper provides a novel methodology that central banks may use to estimate and monitor the speed of absolute and relative price convergence in the Eurozone.

The literature disagrees on inflation convergence in the EMU area after the Euro inception. Busetti et al. $(2006,2007)$ find inflation convergence only prior to the Euro's inception, while Lopez and Papell (2012) find evidence of inflation convergence before and after the Euro's inception using new panel-data techniques and a larger sample size ${ }^{5}$. However, despite the lack of agreement on inflation convergence before or after the Euro's inception, the literature does agree on significant non-zero inflation differentials across countries since the adoption of the single currency; see Rogers (2007), Berk and Swank (2002), and Engel and Rogers (2004), among others. ${ }^{6}$ This article aims to provide a proper framework to determine whether different price trends in the EMU converged to a common trend asymptotically, ${ }^{7}$ or if these trends remain divergent in the long run.

Price-level targeting or inflation targeting? This question has attracted increasing attention for decades (see Hatcher and Minford (2014), among others). We focus on price level convergence instead of inflation convergence for two reasons. First, this allows us to develop both relative and absolute convergence tests. Second, from studying the asymptotic price level convergence we can study the speed of convergence in the long-run price gap. The literature provides different reasons for the persistence of price level gaps over time, from non-harmonized data-production methodologies across statistical offices to several economic reasons such as heterogeneous productivity, labor market frictions, and trade barriers. More recently, Dvir and Strasser (2018) and Ogrokhina (2019) report empirical evidence against the Law of One Price holding in the EMU, ${ }^{8}$ making it interesting to determine how long deviations from the steady-state inflation rate tend to persist over time. This analysis will require to estimate the persistence in the price level gaps, the portion of the gap that has been reduced, and the long-term remaining gap. Our paper also contributes to this research line.

Social and welfare issues arise when long-term inflation differentials remain positive over time. Following Erosa and Ventura (2002), we can consider inflation as a regressive consumption tax, so countries with lower price levels would pay more to be part of the monetary union, given their higher inflation differential rate with the area. A regressive consumption tax has important distributional effects in an economy, and a non-negligible welfare cost; see Lucas (2000), Lagos and Wright (2005), and Chiu and Molico (2010). Therefore, a process

\footnotetext{
${ }^{5}$ However, previous results should be carefully considered given the slow speed of convergence in the inflation differentials. In fact, using a much larger sample - from 1981 to 1996-Cecchetti et al. (2002) find empirical evidence of a slow inflation speed to convergence (around 9.5 years) across some US cities.

${ }^{6}$ The ECB's monetary policy can explain the existence of persistent inflation differentials in the EMU, as this points to a single inflation rate objective, and the ECB claims that the price level convergence across countries in the EMU would lead to higher inflation differentials; see Duisenberg (2000). In this framework, the convergence costs should reduce in the long run (i.e., the price levels should converge asymptotically, at least in relative terms).

${ }^{7}$ Relative asymptotic convergence implies that cross-section prices share the same stochastic trend, and then the same inflation rates in the long run, while price levels may differ across countries, even in the long run.

${ }^{8}$ Specifically between south and north, in the automobile market, and comparing the prices of individual goods using the Economist Intelligence Unit City Data.
} 
of price level convergence would imply a welfare cost that increases with the initial price level gap. Our methodology is useful in monitoring this cost.

This research also contributes to the literature that studies the optimal inflation rates. Following Schmitt-Grohé and Uribe (2010), a zero inflation rate is considered optimal in the framework of the New Keynesian Model with sticky nominal prices. However, optimal slightly positive inflation rates result from the introduction of a zero lower bound on nominal interest rates (Andrade et al., 2018), labor market frictions (Carlsson and Westermark, 2016), or heterogeneous discount factors (Lepetit, 2018). Along this line, Adam and Weber (2019) show that the optimal inflation rate may be positive if firms' levels of productivity are heterogeneous and prices are sticky. Although an inflation target that depends on each region's productivity level is not possible in practice, there is a consensus that the optimal inflation target should be positive and a little higher, given the EMU structural characteristics. The ECB inflation target since 2003 is $2 \%$. However, given the persistence in EMU countries' price level gaps, should the ECB inflation target be higher? Our analysis opens a research question in this vein.

Finally, this article contributes methodologically to the studies that relate convergence to cointegration. These studies focus mostly on analyzing the steady state of the underlying processes of interest, assuming that convergence was already reached. However, if the convergence process is still in progress, as in "catching-up convergence," common cointegration analysis fails to capture asymptotic price level convergence. We consider this situation, and formally define a generalized notion of asymptotic price level convergence in mean (PCM) and variance $(\mathrm{PCV})$, based on the property of cointegration and that adapts to the two existing types of convergence mentioned in the literature: ${ }^{9}$ (i) catching-up convergence (includes a transition path), and (ii) steady state convergence. Additionally, we provide an encompassing model of relative prices that allows for a convergence path driven by an exogenous and straightforward deterministic input. Finally, we describe how to test convergence in mean and variance according to the PCM and PCV definitions provided. Our analysis focuses on the period IV/2001 to IV/2011 to avoid potential biases in the results due to the European Sovereign Debt Crisis. ${ }^{10}$ The analysis of the sensitivity of the convergence process to the liquidity provision programs after this date requires a separate research paper. The analysis included in this paper is designed to clarify the convergence process and the speed of convergence among the EMU countries' price levels after the Euro entered circulation, physically, on the first day of 2002. ${ }^{11}$ On the convergence process and its speed, we conclude that only the France-Germany and Italy-Germany relative price levels show convergence in an absolute sense as defined in Section 2. Only $18 \%$ of relative prices show relative convergence, which represents a stable convergence path, in the long run. ${ }^{12}$ Interestingly, France, Italy, Spain, and Portugal present a stable convergence path with respect to Germany, the largest EMU economy. However, the price gap is still significantly positive at the end of 2011 for Spain and Portugal, which could be a matter of concern since it is indicative of lack

\footnotetext{
${ }^{9}$ See Sturm et al. (2009) for a review.

${ }^{10}$ Our sample includes the financial crisis period. Nevertheless, the ECB liquidity provision programs during the financial crisis concerned all the Eurozone, while liquidity provision programs during the European Sovereign Debt crisis mostly influenced Greece, Italy, and Spain, de Andoain et al. (2016). Following Quint and Tristani (2017), "the impact of liquidity shocks during the financial crisis on inflation and aggregate consumption is estimated to be very minor."

${ }^{11}$ However, our starting sample is 85 quarterly observations between I/1996-IV 2016.

${ }^{12}$ France/Germany, Italy/Germany, Portugal/Germany, Spain/Germany, Italy/Austria, Spain/Austria, Greece/Belgium, Italy/Belgium, Portugal/France, and Spain/The Netherlands.
} 
of convergence. On the other hand, the relative price of Austria-Italy is the only case that shows evidence of convergence in variance, suggesting similar price level reaction to endogenous and exogenous shocks in the short run for both countries. Our empirical and theoretical results provide a formal framework to test relative and absolute price convergence, helping policymakers understand the scope of their monetary policy relative to the inflation rate convergence among EMU countries.

The remainder of the paper is organized as follows. Section 2 introduces the theoretical framework and presents the definitions used throughout. Section 3 describes the model, the econometric representation of convergence, and the hypothesis testing procedures. Section 4 reports the empirical results, and Section 5 concludes.

\section{Theoretical framework}

This section describes and links the concepts of inflation, price level convergence, and the structure of markets. We establish assumptions about the relationship between the countries for which we analyze the price levels.

Let $P_{i, t}$ stand for the aggregate price level of country $i$ at time $t$. In this case, we denote inflation as the logarithmic difference in the aggregate price level, $\pi_{i, t}=\Delta \ln P_{i, t}=$ $\ln P_{i, t}-\ln P_{i, t-1}$. If $P_{j, t}$ is the price level of country $j$ at time $t$, then we can represent the relative price levels of country $i$ with respect to country $j$ by the logarithm of the relative price levels, $r_{i, t}=\ln \left(P_{i, t} / P_{j, t}\right)=\ln P_{i, t}-\ln P_{j, t}$. For simplicity, we refer to the $\log$ price level $(s)$ hereinafter as price(s) and the logarithm of the relative price level(s) as relative price $(\mathrm{s}){ }^{13}$

Whether the inflation rate is a stationary or nonstationary process is still unknown. We build on the idea that prices need at least one first difference to be stationary, and ADF tests on the inflation series support our claim. Drawing on economic theory, we expect that any market-clearing nominal price follows a non-stationary process over time. This expectation reflects the idea that shifts in supply or demand imply price adjustments to clear the market in the long run. Given that the price level is an aggregate, aggregating the stochastically non-stationary processes should produce a non-stationary process.

\subsection{Inflation background}

The definition of inflation has been a hot topic in economics. Bronfenbrenner and Holzman (1963) discussed around 13 possible definitions of inflation, which was a small sample of the definitions available at that time. Twelve years later, Laidler and Parkin (1975) presented another survey on inflation, using only one definition: "Inflation is a process of continuously rising prices, or equivalently, of a continuously falling value of money," thus defining inflation as a purely monetary phenomenon. ${ }^{14}$ Recently, however, there has been a lack of debate about the inflation concept, and no revised definition has been presented. ${ }^{15}$ There seems to be a consensus among scholars about the appropriate definition, as stated by Friedman (1963):

\footnotetext{
${ }^{13}$ We use the natural-base logarithm for all variables in this study.

${ }^{14}$ See Laidler and Parkin (1975) p. 741.

${ }^{15}$ There is growing literature concluding whether inflation has become a different-than-monetary phenomenon after the Great Financial Crisis (GFC). This paper focuses on the dynamics of relative prices within the EMU area from 2001 to 2011 without an in-depth analysis of main inflation drivers in this period.
} 
"By inflation, I shall mean a steady and sustained rise in prices." 16 However, the terms "steady" and "sustained" are ambiguous, and are not formally defined in Friedman (1963). It is common to interpret these terms in relation to the long-run statistical equilibrium. Related to this, Beveridge and Nelson (1981) propose a decomposition of non-stationary time series between a transitory and a permanent component, where the long-run forecast represents the permanent component. ${ }^{17}$ Then, the inflation rate, denoted by $\pi_{t}$, can be decomposed as a (stochastic) trend, $\pi_{t}^{*}$, plus an inflation gap $\varepsilon_{t}=\pi_{t}-\pi_{t}^{*}$. Combining Beveridge-Nelson's decomposition with Friedman's inflation definition, we define the trend inflation as:

Definition 1 The permanent inflation component, $\pi_{t}^{*}$, is the expected variation of the price level in the long run:

$$
\pi_{t}^{*}=\lim _{k \rightarrow \infty} \mathbb{E}\left[\pi_{t+k} \mid \mathcal{F}_{t}\right]
$$

where $\mathcal{F}_{t}$ denotes all information available at period $t$.

Therefore, we associate Laidler and Parkin (1975) and Friedman (1963)'s inflation definitions as a purely monetary phenomenon in the trend inflation, $\pi_{t}^{*}$, and we assume that the transitory component, $\varepsilon_{t}$, is driven by non-monetary shocks (non-monetary phenomenon such as changes in raw materials prices, etc.). Definition 1 coincides with Friedman's when prices follow an I(1) process with drift. In such a case, the trend inflation is stationary and the long-run rise in prices would be "steady" and "sustained."

Recently, several authors, such as Ireland (2007), Stock and Watson (2007), Cogley and Sbordone (2008), and Cogley et al. (2010), among others, used this inflation decomposition. Their works differ on the assumptions about the permanent and transitory components. A driftless random walk is usually used as trend inflation, while stationary serially uncorrelated or correlated noise is used for the inflation gap. We make no assumptions on these components as we believe these will depend on the data. We will extract this information from the sample in our empirical exercise below.

The previous definition also has implications in terms of inflation monitoring and control. As Ireland (2007) finds, if inflation is an "always and everywhere" monetary phenomenon, then "permanent changes in the inflation rate cannot occur without corresponding changes in the central bank inflation target." 18 This statement holds irrespective of whether the target is publicly announced. Thus, having inflation under control implies that the permanent inflation component from Definition 1 should be constant, $\pi_{t}^{*}=\pi^{*}$, when the inflation target is a constant rate. This should be the case in the EMU, as the Governing Council of the ECB clarified that, "in the pursuit of price stability, it aims to maintain inflation rates below, but close to, $2 \%$ over the medium term." 19

\footnotetext{
${ }^{16}$ See Friedman (1963) p. 39.

${ }^{17}$ Friedman (1963) also proposed a decomposition into transitory and permanent components based on exponential smoothing. However, the Beveridge and Nelson (1981) decomposition offers a more general framework, in which Friedman's approach is only a special case.

${ }^{18}$ The dictum of Friedman, "always and everywhere" is presented formally in the model by Ireland (2007), p. 1859 .

${ }^{19}$ See the definition of price stability in https://www.ecb.europa.eu/mopo/strategy/pricestab/html/ index.en.html.
} 


\section{$2.2 \quad$ Relative price level}

In a monetary union with different fiscal policies, productivity, and so on, as is the case of the EMU, measuring and controlling inflation is different from a single country situation. In this special case, price level convergence should be tested. For the bivariate case, that is, two countries, the analogous concept of trend inflation is the long-run gap between the price levels, which is equivalent to the relative price level rate in the long run. Inflation is a relative rate in the time domain, but here, we also pay attention to the long-run relative rate in the space domain. This notion is about how expensive a country is with respect to another one and how this relationship evolves in the long run. Note that, as Cecchetti et al. (2002) states, "if the relative price levels contain a unit root, it would mean that the nominal price levels would wander apart indefinitely" and any prior shocks would have a permanent impact. Then, the relative price level rate, denote by $\tau_{i j, t}$, can be decomposed as a (stochastic) relative price trend, $\tau_{i j, t}^{*}$, plus a price gap $\gamma_{i j, t}=\tau_{i j, t}-\tau_{i j, t}^{*}$.

According to this definition, and building on Definition 1, we define the relative price trend (permanent relative price component) as:

Definition 2 The permanent relative price component, $\tau_{i j, t}^{*}$, for country $i$ with respect to country $j$, is the expected (log) relative price level in the long run, formally:

$$
\tau_{i j, t}^{*}=\lim _{k \rightarrow \infty} \mathbb{E}\left[r_{i j, t+k} \mid \mathcal{F}_{t}\right]
$$

We now hypothesize what would happen if prices in two different countries are I(1). If the relative price level contains a unit root, then it would imply that the nominal prices do not share a common trend. In this case, the $(\log )$ price differentials will evolve across time according to relative economic performance, the different monetary and/or fiscal policies, and so on. On the contrary, if the relative price level is stationary, then its permanent component (as in Definition 2) will be constant over time, that is, $\tau_{i j, t}^{*}=\tau_{i j}^{*}$, which implies that the nominal prices will share a common trend, and any prior shock would have a transitory impact in prices. As nominal prices are assumed to be I(1), they will be cointegrated with a cointegrating vector $(1,-1){ }^{20}$

\subsection{Asymptotic price level convergence}

The definitions of Asymptotic Price Level Convergence in Mean (PCM) and Asymptotic Price Level Convergence in Variance (PCV) are presented here.

\subsubsection{Asymptotic price level convergence in Mean (PCM)}

In the following, we assume that all nominal prices are $\mathrm{I}(1)$ and therefore, inflation rates are stationary. $^{21}$ Under this assumption, and the Law of One Price, all price levels in a monetary union should converge to long-run statistical equilibrium, sharing a long-run trend. Therefore, the relative PPP should hold, at least asymptotically. Otherwise, the monetary authority will not be in a position to establish a common monetary policy that is optimal in

\footnotetext{
${ }^{20}$ For our case, a different value from unity for the cointegration parameter makes no sense, as the countries share the same monetary unit and we assume neutrality of the money in the long run. However, it is easy to extend this framework to a pool of countries that do not share the same monetary unit, or if the analyst wants to test the neutrality of money in the long run.

${ }^{21} \mathrm{ADF}$ tests for our price level series support this claim.
} 
a theoretical sense. When a monetary union has multiple price levels, such that the relative PPP does not hold, then the monetary policy could also be ineffective. For example, let us assume that there are different I(1) price levels in a monetary union, but that they are divided into two groups sharing one trend each. Any attempt to carry out a coordinated monetary policy could cause different problems, and any prior endogenous or exogenous shocks would have a permanent impact. For instance, a contractionary monetary policy that aims to reduce the inflation on one side of the union could cause a recession on the other side. In contrast, the need for an expansionary monetary policy to avoid a recession on one side could raise inflation on the other. Large inflation differentials can cause real interest rate differences and a persistent loss of relative competitiveness, which is not sustainable in the long-term; see, for example Cecchetti et al. (2002) and Engel and Rogers (2004).

Therefore, a real coordinated monetary policy requires a time-invariant trend for relative prices. Nominal prices could differ, but their non-stationary factor should be common. Price levels for all members should be cointegrated so the monetary authority can control all of them simultaneously. Further, price level trends could be different for a while, but their longrun path should converge, at least to a constant gap that could be explained by structural differences. To capture this idea, we define the asymptotic PCM as follows,

Definition 3 For the asymptotic PCM, the price levels in countries $i$ and $j$ converge asymptotically if

$$
\lim _{k \rightarrow \infty} \mathbb{E}\left[r_{i j, t+k} \mid \mathcal{F}_{t}\right]=\tau_{i j}^{*}
$$

holds for all t and with probability 1 , where $\tau_{i j}^{*}$ is the long-term forecasts of the $(\log )$ price level differentials and is a constant. Using the same terms as Durlauf and Quah (1999), we say that there is relative convergence (relative PPP) if $\tau_{i j}^{*}$ is a non-zero constant, and the convergence is absolute (absolute PPP) if the long-run gap is zero, $\tau_{i j}^{*}=0$.

Definition 4 If $r_{i j, t}=\ln P_{i t}-\ln P_{j t}$ is a stationary process with finite mean and variance, with $r_{i j, t}=\ln P_{i t}-\ln P_{j t}$, and $\lim _{k \rightarrow \infty} \mathbb{E}\left[r_{i j, t+k} \mid \mathcal{F}_{t}\right]=\tau_{i j}^{*}$, then

(i) $P_{i}$ and $P_{j}$ converge in an absolute sense if $\tau_{i j}^{*}=0$,

(ii) $P_{i}$ and $P_{j}$ converge in a relative sense if $\tau_{i j}^{*}=c \neq 0$, with $c \in\{\mathbb{R}-\{0\}\}$

These definitions allow us to represent a process in which the price series have already converged, called convergence as steady state, or are in a converging process, convergence as a catching up, that permits a price differential to converge to a constant. This definition is in the interest of the control of inflation in a monetary union. It implies that the relative prices should follow a stationary process or, at least, tend to an asymptotically stationary process.

Note that the absolute convergence condition implies that the PPP is fulfilled. However, the absolute PPP does not apply in a strict sense for the price levels because they consist of tradable and non-tradable goods prices. When the price aggregates include only tradable goods, and assuming perfect competition, no trade barriers, and no transport costs, the convergence should be absolute, and $\tau_{i i}^{*}=0$. However, when the price aggregates also include 
non-tradable goods, the price level differentials will depend on the difference between the fundamentals of the economies, such as productivity and welfare levels, so that we would expect only relative convergence in most cases, that is, relative PPP. This is also true when there are different weights for each country's market basket, as Dornbusch (1987) discussed. We test for both convergence types in this article.

\subsubsection{Asymptotic price level convergence in Variance (PCV)}

An efficient monetary union requires not only PCM but also that shocks to the log-price ratio $r_{i j}$ are transient for all country members. There can be small differences in the price level responses due to particular country-specific factors, but these should tend to zero in the financial market integration process, so that the variance of the log-ratio of prices tends to zero or to a constant. Otherwise, a coordinated monetary policy (endogenous shock) may end in heterogeneous effects by country.

Thus, we define the second condition for an efficient monetary union (Definition 5) as price convergence in variance $(\mathrm{PCV})$. PCV definition requires that the stochastic process $r_{i j}$ is asymptotically stationary and has a limiting distribution with finite variance. This implies that endogenous or exogenous shocks (to the $\log$ price ratio $r_{i j}=\ln P_{i}-\ln P_{j}$ ) are transient within the monetary union such that the variance of the log-ratio of prices convergences to zero or to a constant. ${ }^{22}$ This way, regardless of the price levels reaction to exogenous or endogenous shocks, a monetary union becomes more efficient if the dispersion of relative prices' shocks tend to decrease.

Hence, it would be worthwhile to consider a definition of convergence that includes the notion of convergence in variance for price levels. Thus, we complement Definition 3 with the following definition:

Definition 5 For the $P C V$, the price levels in countries $i$ and $j$ converge asymptotically if

$$
\lim _{k \rightarrow \infty} \mathbb{E}\left[\left(r_{i j, t+k}-\tau_{i j}^{*}\right)^{2} \mid \mathcal{F}_{t}\right]=v_{i j}
$$

holds for all $\mathrm{t}$ and with probability 1 , where $v_{i j}$ is a constant that represents the asymptotic expected variance of the relative prices.

Given this definition, absolute convergence in the distribution, $v_{i j}=0$, implies absolute $\mathrm{PPP}$ in distribution, and relative convergence in distribution, $v_{i j} \neq 0$, implies relative PPP in the distribution (assuming normality of the process).

If the PCM and PCV requirements hold for a pair of countries, then there is price level convergence in distribution for both countries, under the assumptions of Gaussianity and the asymptotic expected variance of the relative prices. Note that if both requirements hold for a pair of countries, then their inflation rates are the same. Obviously, absolute convergence in distribution is hard to find in practice. However, although they might appear to be Utopian, the concept is useful to understand the relationship between price level convergence and money market integration.

\footnotetext{
${ }^{22}$ If PCM holds and PCV does not there is no convergence or this is incomplete, at least from an economic and statistical point of view.
} 


\section{$3 \quad$ Model and hypothesis testing}

We use an encompassing model for the price differentials to represent price level convergence. Formally, we can write the model for the relative price level for two countries, including a convergence path, as

$$
\begin{aligned}
r_{i j, t} & =D_{i j, t}+S_{i j, t}, \\
D_{i j, t} & =\mu_{i j}+C_{i j, t}, \\
\phi_{i j, p}(B) S_{i j, t} & =\theta_{i j, q}(B) a_{i j, t},
\end{aligned}
$$

where $B$ is the backshift (or lag) operator, such that $B^{d} P_{t}=P_{t-d}$, and the price level differential has an additive decomposition with a deterministic component, $D_{i j, t}$, and a stochastic component, $S_{i j, t}$. In the deterministic component, $\mu_{i j}$ is the constant mean and $C_{i j}$ is the transient component. ${ }^{23}$ The stochastic component follows a stationary process and has an $\operatorname{ARMA}(p, q)$ representation, being strictly stationary and invertible (that is, the autoregressive and moving average polynomials all have zeros lying outside the unit circle), and $a_{i j, t}$ is a weak white noise process.

Following equation (1), the model employs a linear transfer function to represent the relation between the transient component, $C_{i j, t}$, and an input variable $\xi_{t}^{t^{*}}$. Thus, let $\xi_{t}^{t^{*}}$ describe the effects of an event that will last permanently after time $t^{*}$ as unity when $t>t^{*}$, and zero otherwise. We use this step-at-time- $t^{*}$ sequence to formally define the transition path as follows,

$$
\nu(B) \xi_{t}^{t^{*}}:=\frac{\omega_{s}(B)}{\delta_{r}(B)} \xi_{t}^{t^{*}}
$$

where $\omega_{s}(B)=\omega_{0}-\omega_{1} B-\ldots-\omega_{s} B^{s}, \delta_{r}(B)=1-\delta_{1} B-\ldots-\delta_{r} B^{r}$, there are no common factors between $\omega_{s}(B)$ and $\delta_{r}(B)$, and $s, r$ are non-negative integers. The concept of convergence is closely linked to stability, and we consequently require $\delta_{r}(B)$ to be stable; that is, the roots of the characteristic equation $\delta_{r}(B)=0$ lie outside the unit circle. We can obtain two interesting parameters from the stable transition path defined in (2): i) the steady-state gain, $g$, defined as $g:=\sum_{k=0}^{\infty} \nu_{k}=\nu(1)<\infty$; and ii) the mean lag of response, $l:=\nu^{\prime}(B) /\left.\nu(B)\right|_{B=1}$, where $\nu^{\prime}(B)$ is the derivative of $\nu(B)$ with respect to $B$, which measures the speed of convergence when the response is monotone. Note that our transition path is related to the literature on level shifts. For $s=0$ and $r=0$, the transition path results in an abrupt shift in the level, known as an additive outlier, while for $s=0$ and $r>0$, it allows for a smooth shift from the initial level to a new one, known as an innovational outlier.

As an example, a transition path could be represented by a smooth monotone response, with $\nu(B)=\omega_{0} /\left(1-\delta_{1} B\right)$ and $0<\delta_{1}<1$, reflecting the fact that agents are not likely to react all at once because of, for instance, market inefficiencies. On the contrary, the same

\footnotetext{
${ }^{23}$ We omit the seasonal terms for simplicity. However, $D_{i j, t}$ is the deterministic seasonal component in the deterministic component with an annual sum equal to zero for all $t$. For quarterly data $D_{i j, t}$ has a non-zero value, but the sum of the four consecutive values equals zero. The trigonometric representation for the deterministic seasonality component proposed takes the form $\alpha_{1} \cos (\pi / 2) t+\beta_{1} \sin (\pi / 2) t+\alpha_{2}(-1)^{t}$, which is equivalent to the traditional approach in the literature that uses the weighted sum of four seasonal dummy variables.
} 
$\nu(B)$ but with $\delta_{1}=1$ would imply a $\omega_{0}$-slope linear transition. ${ }^{24}$ Figure 1 shows an example of $\nu(B) \xi_{t}^{t^{*}}$ that represents a gradual monotone convergence path.

\subsection{Testing the PCM}

For the requirement of convergence in mean, both price levels will have converged asymptotically (i) in a relative sense if the log-ratio $r_{i j, t}$ follows a stationary process, and (ii) in an absolute sense if $D_{i j, t}$ is equal to zero, or converged asymptotically if $D_{i j, t}$ tends to zero as $t$ approaches infinity.

Figure 1: Example of convergence path subject to $\omega_{0}>0$ and $0<\delta_{1}<1$.
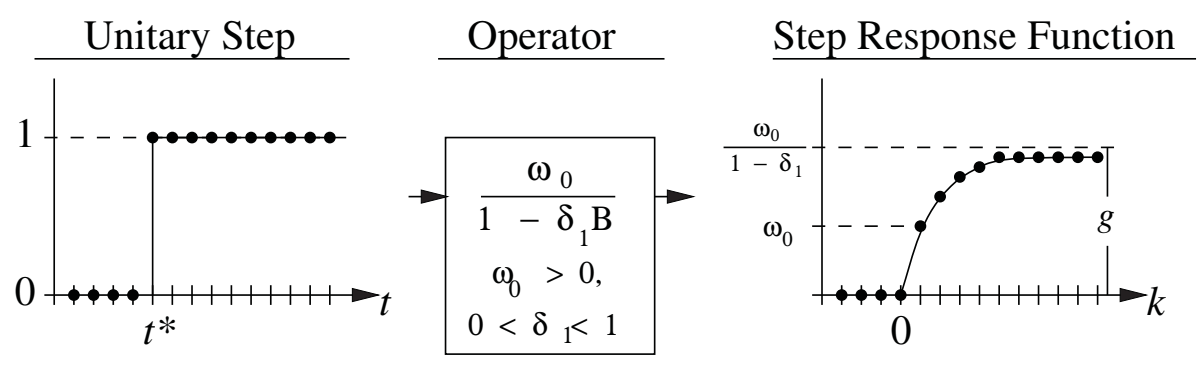

As the price levels analyzed are from the same currency area, only a cointegration vector $(1,-1)$ is feasible between a pair of price levels. Different values for the cointegration vector imply long-run monetary illusion in a common currency area, which is unlikely. For instance, we do not need a multivariate model, in this case, to study cointegration and convergence by pairs. We can estimate equation (1) easily for a univariate model of the relative price, $r_{i j, t}$, as well as to perform unit root tests. This not only simplifies the analysis but also has gains for the power of the unit root tests as the critical values are closer to zero. In this case, Saikkonen and Lutkepohl (2002), hereafter SL-GLS, present a test for a unit root with different level shifts that include the transition path (2). They show that the convergence parameters in $\nu_{i j}(B)$, or the time at which the convergence begins, $t^{*}$, do not affect the limiting distribution of the non-stationarity test. Furthermore, the Shin and Fuller (1998) test (SF), which has more power than ADF-type tests in the case of ARMA structures, can also be used.

When the non-stationarity hypothesis is rejected in the univariate version of equation (1), standard inference applies. Steady state convergence, in the sense of Bernard and Durlauf $(1995,1996)$, arises when $D_{i j, t}$ is equal to zero for all time $t$. In this case, $C_{i j, t}=0$ in equation (1), and the null hypothesis is $\mu_{i j}=0$. In contrast, there is catching-up convergence if $D_{i j, t}$ tends to zero as $t$ approaches infinity.

To test catching-up convergence, it is necessary to estimate the long-run gains of the convergence path. With the initial conditions, represented by the constant mean, $\mu_{i j}$, and the long-run gains, $g_{i j}$, having the same value, but with opposite signs, there is evidence of convergence in the mean (see Figure 1).

\footnotetext{
${ }^{24}$ This linear transition is common in the literature on price convergence, but has three important drawbacks: it is i) very restrictive, ii) very abrupt, and iii) requires not only the date when the convergence starts, but also when it ends; otherwise, no convergence representation is possible.
} 
To test the null hypothesis in (3) that the long-run gap is equal to zero, we use the two procedures below, the t-student and delta method and the likelihood-ratio test.

$$
\begin{array}{ll}
H_{0}: & \tau_{i j}^{*}=\mu_{i j}+g_{i j}=0 \\
H_{1}: & \tau_{i j}^{*}=\mu_{i j}+g_{i j} \neq 0
\end{array}
$$

1. T-student and Delta Method:

Assume that $\hat{g}_{i j}$ and $\hat{\mu}_{i j}$ are consistent and asymptotically normal estimators of $g_{i j}$ and $\mu_{i j}$, respectively, so that $\sqrt{T}\left(\hat{\tau}_{i j}-\tau_{i j}\right) / \hat{\sigma}_{\tau} \stackrel{d}{\rightarrow} N(0,1)$, where we calculate $\hat{\tau}_{i j}$ and $\hat{\sigma}_{\tau}$ using the Delta Method.

2. Likelihood-ratio test:

For the same purpose, the statistic $-2 \log l\left(\Theta_{2} \mid P_{1, t}, P_{2, t}, \xi_{t}^{t^{*}}\right) / l\left(\Theta_{1} \mid P_{1, t}, P_{2, t}, \xi_{t}^{t^{*}}\right)$, where $\Theta_{2}=\left\{\alpha, \omega_{0}, \ldots, \omega_{s}, \delta_{1}, \ldots, \delta_{r}, \phi_{1, i i}, \ldots, \phi_{p, i i}, \theta_{1, i i}, \ldots, \theta_{q, i i}, \theta_{i j}\right\}$, and which follows a $\chi^{2}$ distribution asymptotically with 1 degree of freedom, can be applied.

Regardless the test used, when $P_{i, t}$ and $P_{j, t}$ are cointegrated and $H_{0}$ in (3) cannot be rejected, then $P_{i, t}$ and $P_{j, t}$ are said to converge asymptotically in mean.

\subsection{Testing the asymptotic PCV}

Testing PCV requires a test of whether the residual variance in equation (1) tends to zero. To keep the analysis simple, we propose using the test by Breusch and Pagan (1979), which tests whether the estimated variance of the residuals is unconditionally homoscedastic. We regress the squared residuals on an exogenous variable. The Lagrange multiplier test statistic, LM, is the product of the coefficient of determination $\left(R^{2}\right)$ from this regression and the sample size $n$, namely $L M=n R^{2}$. The test statistic is asymptotically distributed as $\chi^{2}(1)$ under the null hypothesis of homoscedasticity.

If the null hypothesis is not rejected, then there is no evidence in favor of PCV, as the variance of $a_{i j t}$ is constant over time. In that case, PCV, and therefore increasing price convergence in distribution through increasing money market efficiency, can be rejected. Unfortunately, when the null hypothesis is rejected, we cannot conclude that there is PCV, as PCV implies heteroscedasticity, but the reverse is not always true. In that case, we could have growing integration or, conversely, disintegration.

In the inconclusive case, we propose observing the evolution of the standard deviation of the innovation (SDI). We can thus use this visual aid to determine the evolution of the variance, the PCV, and finally, the process of price convergence. If the SDI series show a decreasing pattern, we can argue that there is a growing integration. This series can be estimated with a rolling window using the residual standard deviation from equation (1).

\section{Empirical results: Price convergence}

In this section, we apply the model represented by equation (1) to the harmonized Consumer Price Index for the EMU countries. We aim to investigate whether there is price level convergence among the members of the monetary union and if that convergence was triggered by the establishment of the common currency. 


\subsection{Data and estimation results}

In our study, we analyze the harmonized Consumer Price Index for the EMU countries from $\mathrm{I} / 2001$ to IV/2011. However, let us include in this section a brief study of the 85 quarterly observations for this series between I/1996-IV/2016, which includes the pre- and post-sample periods. The data were originally not seasonally adjusted monthly series and were aggregated quarterly by taking the simple average. In order to make the analysis comparable, we change the base to December 2001, and then weight the index for the comparative price levels to Germany at the end of 2001 . We sourced the original series from Eurostat. ${ }^{25}$

Figure 2 depicts the price levels. As expected, different clubs appear in the EMU. The first club, with the highest levels, is made up of Ireland and Finland. The second club comprises Austria, Belgium, Germany, France, Italy, and the Netherlands. Finally, Portugal, Greece, and Spain show the lowest price levels in the EMU.

The relative prices in the EMU give a clearer picture of convergence-or the lack thereof. Figure 3 shows the relative prices with respect to Germany, except for the cases of Ireland and Finland. In the case of France, there is a visual convergence pattern to parity since the beginning of 2002: (i) a catching up convergence to parity between 2002 until 2005, (ii) a steady-state convergence between 2005 and 2012, and (iii) a slight divergence pattern since 2012, most probably caused by the debt crisis in the EMU. The rest of the second club also seems to converge to German prices, but the picture is not as clear as in the French case. A more detailed statistical analysis is required to check this hypothesis. In any case, we observe that the price levels are slightly higher at the end of the sample period for all the countries. The Italian/German relative price is at a low level (the lowest in its club) at the beginning of the sample and practically converged to parity by the end. Price levels became very similar in Germany and Italy 10 years after the Euro was established. For the lowest club, as expected, the positive slope of the relative price is higher. Both Spain and Greece exhibit a positive and possibly linear trend in their relative prices. Portugal's relative series seems to show a convergence pattern with Germany, although this occurs far from parity.

Although this paper presents a statistical exercise, and we do not investigate the underlying drivers of these gaps, we hypothesize that the price levels relative to Germany increased most probably due to the establishment of the common currency, as there is no evidence, or ambiguous evidence, of productivity convergence across the EMU after the Euro. ${ }^{26}$ To be consistent with this hypothesis and the set-up presented in Section 2, we restrict the sample to 41 quarterly observations between IV/2001 and IV/2011. We include the last observation of 2001 as the initial condition given that the Euro was introduced in a physical form in January 2002. ${ }^{27}$ We also exclude the data after 2011 and include the last observation of 2011 to avoid a potential divergence process due to the debt crisis in the EMU. This debt crisis could have a permanent or transitory effect on the convergence process; however, we do not have enough data yet to test the nature of this effect. ${ }^{28}$ Thus, to avoid the potential bias against the convergence hypothesis, we focus only on 2002-2011 data window. Results

\footnotetext{
${ }^{25}$ Further details and the transformed series are in a detailed Statistical Data Appendix, which is available on request from the authors

${ }^{26}$ See Sondermann (2014), among others.

${ }^{27}$ While the Euro was introduced in a non-physical form in 1999, we are conservative in this sample selection and include only the data after 2001.

${ }^{28} \mathrm{An}$ empirical study of this regard is out of the scope of this study, but is clearly an interesting question for exploration in future research.
} 
reported for this paper might be considered as a necessary first exercise in studies considering larger sample sizes. Besides these historical reasons, Figures 2 and 3, also support this sample selection decision.

Our analysis shows that all nominal price levels have similar statistical properties. The model specification for these price level series is relatively simple. Nominal prices: (i) are integrated of order one; (ii) have an order-one, in most cases, or an order-two autoregressive structure for the stochastic part; and (iii) have a constant mean, $\mu_{i}$, and a seasonal component, for the deterministic part. ${ }^{29}$

Table 1 summarizes the results. We also report the estimated parameters and some diagnostic tools, except those related to seasonal modeling. All parameters are statistically different from zero, and in all models, the $Q$-statistic by Ljung and Box (1978) shows no sign of misspecification.

In all cases, the SF unit root test rejects the null hypothesis of non-stationarity of the $\mathrm{AR}(1)$. Moreover, there is no evidence of an invertible representation if we add a second difference and an MA(1) operator to control over-differentiation; the GLR test cannot reject the null hypothesis of non-invertibility in these alternative models. Consequently, I(1) is confirmed in these nominal price levels. This fact implies that we can represent inflation in these countries as a constant value; see Definition 1 . Thus, the quarterly inflation rate is estimated by the mean, $\hat{\mu}$.

According to the results and the sample period, the EMU countries with the lowest inflation are Germany and Finland, with quarterly inflation rates of $0.43 \% \pm 0.12$ and $0.43 \% \pm 0.20$, respectively, at $95 \%$ confidence. In contrast, the countries with the highest inflation rates are Greece and Spain, at $0.76 \% \pm 0.20$ and $0.71 \% \pm 0.20$, respectively. ${ }^{30}$ Moreover, the differences in inflation volatility are also non-negligible. Greece, Portugal, and Spain show the highest quarterly volatility levels, above $0.45 \%$. In contrast, France and Germany are slightly below $0.31 \%$. Therefore, the strategy the ECB follows, where "price stability is defined as a yearon-year increase in the Harmonised Index of Consumer Prices (HICP) for the euro area of below 2\%" held for all countries in the EMU except Spain and Greece.

Unlike the inflation rates, relative prices do not seem to be stationary: see Figure 3 for the EMU's relative prices with respect to Germany. In all but Finland and Ireland, a deterministic transient component seems to be necessary to obtain a stationary representation.

We deliberately fix $t^{*}$ to the quarter at which the convergence could have started, at the beginning of the sample in the first quarter of 2002. This is because the Euro entered circulation, physically, on the first day of 2002, and we can empirically test if this fact had a significant effect in terms of price level convergence in the EMU. In any case, despite the historical and empirical reasons that justify the use of this quarter as the initial point for the convergence process, we carried out a thorough search looking for alternative starting dates within the sample. For each case presented in this section, we estimate models with different convergence operators for later quarters, without finding any significant result.

\footnotetext{
${ }^{29}$ The initial specification for the stochastic part is according to pacf values, AIC, and H-Q criteria. The three criteria are in line with the same initial specification.

${ }^{30}$ In order to obtain the annual inflation rates, the quarterly rates should be multiplied by four.
} 
With $t^{*}$ fixed to I/2002, we fit equation (1) to every relative price series. Note that the stochastic structure is restricted to be univariate. This is more a virtue than a drawback, as making the models simpler avoids computational issues, particularly when the samples are short, as in our case.

Table 2 reports the estimation results with German prices as the numéraire. ${ }^{31}$ The model identified in each case is also relatively simple: (i) an $\mathrm{AR}(1)$ process for the stochastic part in most cases, although $\mathrm{AR}(2)$ or $\mathrm{AR}(3)$ structures are estimated in a few cases; (ii) a mean, $\mu$; and (iii) a gradual and monotone convergence path, $\omega_{0} /\left(1-\delta_{1} B\right)$. We also present the estimated parameters with their standard deviations and some diagnostic tools.

In most of the EMU relative price series, we detected a unit root, or it was not possible to estimate a stable convergence path. The likely reason is that these convergence processes were so slow and gradual that the most appropriate representation is very close to a positively sloped straight line $\left(\delta_{1} \simeq 1\right.$, see Section 3.1).

However, adding a transient component seems to be sufficient to represent the transition path and obtain a stationary representation in some particular cases. There, the estimated parameters are statistically different from zero, the convergence operator is stable in most cases, and the diagnostic statistics show no sign of misspecification. More detail on these cases is given in the next section.

\subsection{Testing the PCM}

We test the PCM hypothesis stated in Definition 3 for the EMU countries mentioned, and describe the convergence process to a hypothetical unique price level that could have emerged at some point after the year 2001.

Testing the PCM requires the relative prices to follow a stationary process or a transitionstationary process with a stable convergence path. These conditions were previously verified using the estimates of equation (1) for all possible relative prices. After that, we test the PCM hypothesis in every relative price series in the EMU.

Table 3, Panel A, shows the results of the SF unit root tests. With Germany as the numéraire, we reject non-stationarity only for France, Italy, Portugal, Greece, and Spain when a transition term is introduced from $t^{*}$. When France is the numéraire, non-stationarity is also rejected for Spain and Italy, which have common land borders, besides Germany, Greece, Italy, Netherlands, and Portugal. In short, only $45 \%$ of the total pairwise relative prices can be represented as transition-stationary processes. The same tests generally do not reject non-stationarity at any standard level for all possible relative prices when there is no transient component in the model. This reveals evidence of asymptotic PCM as "catchingup" and implicitly rejects convergence as a "steady state."

We perform the formal test for the stability of the convergence operator $\left(\mathrm{H}_{0}: \delta_{1}=1\right.$ vs. $\left.\mathrm{H}_{1}: \delta_{1}<1\right)$ only for the relative prices that are transition-stationary. Table 3 , Panel B reports the results of this test. Only a few cases present a stable convergence path. The cases in which the null hypothesis is rejected in favor of the alternative are: 1)

\footnotetext{
${ }^{31}$ All the estimation results for all possible relative prices are available under request from the authors.
} 
France/Germany, Italy/Germany, Portugal/Germany, and Spain/Germany, 2) Italy/Austria and Spain/Austria, 3) Greece/Belgium and Italy/Belgium, 4) Portugal/France, and, 5) the Netherlands/Spain. We can then conduct the PCM test for these ten cases.

Table 4, Panel A provides the results of the tests for PCM $\left(\mathrm{H}_{0}: \tau_{i j}^{*}=g_{i j}+\mu_{i j}=0\right.$ versus $\mathrm{H}_{1}: \tau_{i j}^{*} \neq 0$ ) employing the student- $t$ statistics. ${ }^{32}$ Both the student- $t$ and LR tests strongly confirm that the price levels in France and Italy hold the PCM relative to Germany, which means that the remaining gap is not statistically different from zero. Since the beginning of 2002, the catching-up of the French price level was around 2\%, and fast: in 5.9 quarters, half of the total effect was reached. Meanwhile, the catching-up of the Italy price level was relatively big, around $6.9 \%$, and very slow: in 25 quarters, half of the total effect was reached (see Table 4, Panel B).

In other cases, the remaining gap is statistically different from zero. Thus the long-run price level in Portugal is lower than that of Germany at around 17.4\%. The catching-up of the Portuguese prices with the German prices was around $5.6 \%$, although a little faster than in the French case (5.6 quarters to reach half of the gain). In the case of Austria and Italy, the remaining long-run gap is small, at $1.2 \%$ lower in Italy, although still significant. In this case, the reduction of the initial gap, $\hat{g}$, was $4.5 \%$, but it took longer (13.8 quarters) to reach half of the total catching-up.

Particularly interesting is the case of Spain, as the catching-up observed is more pronounced than in any other case. The long-run gain in Spanish prices relative to those of Germany, Austria, and the Netherlands is roughly $12.4 \%, 12.5 \%$, and $10.3 \%$, respectively. The speed is relatively slow, around 19 quarters in the first case, 27 quarters in the second, and 12 in the last one.

These results are not counterintuitive but deserve some explanation. The results for the France/Germany relative price perfectly fit the predictions of the economic theory. The two countries have relatively similar economies and their common border facilitates commercial activities. The Law of One Price applies in its strict form and we prove that ten years after the establishment of the common currency, their prices have strictly converged in mean. Then, why this does not occur between all price pairs? The economies that show weak convergence in their prices (with lower values for the $t$-test in Table 4, Panel A), specifically Austria/Italy, show many similarities. In the case of Austria and Italy, it is probable that the North part of Italy presents much more similar prices (and thus mean convergence in a strict form, mean absolute convergence) than does the South. An analysis of regional prices could evaluate this thesis. The cases of Portugal/Germany, Portugal/France, Spain/Austria, and Spain/Netherlands are more surprising. Our guess is that two different effects are at work here, and, most probably, for all relative prices. There is probably a convergence in tradable goods and services, but the prices of non-tradable goods and services either do not converge, or converge more slowly. Our analysis reflects a combination of both. In any case, one of the implicit results of the analysis is that the ECB's monetary policy does not affect the economies of the EMU equally. Accordingly, one could wonder if the transmission of the monetary policy is equally efficient in all EMU countries.

\footnotetext{
${ }^{32}$ The LR tests are consistent with the student- $t$. For this reason, only the student- $t$ statistics are presented, although the former is available from the authors upon request.
} 
There are, of course, some methodological aspects that we should take into account when analyzing the results. The fact that so many zeros appear in Table 3, Panel B, is clearly related to the sample size. In these cases, the long-run gain is not finite and the test for PCM cannot be performed. A longer sample will definitely improve the analysis, as what we now estimate to be a linear transition path (which has little economic sense) will very likely be estimated as a curved transition with finite gain. Finally, it could be that in some cases, prices are indeed converging (in mean, variance, or both), but the transition path is much more complex than the ones we apply here. Again, a longer sample will give insights in this respect. The exercise that we develop in this article intends to cover the period before the sovereign debt crisis, to understand the price convergence process whitout central bank interventions oriented to assist specific countries.

\subsection{Testing the PCV}

For the stationary relative prices, we perform the formal test for PCV. We use the BreuschPagan test to examine PCV, as explained in Section 3.2. The residuals series are obtained from the models presented in Table 2.

We report the results of the PCV test of EMU prices in Table 5. The statistics for the null hypothesis that the residuals are homoscedastic are not rejected in most cases. Homoscedasticity is rejected only for the Italy/Austria and Italy/Belgium cases at the $5 \%$ level, and for the Netherlands/Spain at the $10 \%$ level. Thus, PCV is only possible for these pairwise relative prices.

In order to see whether the heteroscedasticity detected is generated by a decreasing variance, we draw the evolution of the residual standard deviations of the natural log of relative prices for all cases. We calculate the evolution over time of the residual standard deviations using rolling windows with a span of $t=10$. We provide the illustration in Figure 4. This figure suggests that the standard deviation decreased for the Italy/Austria pair, and conversely, increased for the Italy/Belgium and Netherlands/Spain. Consequently, we can reject PCV for the remaining cases. Here, some considerations are needed. The result for the relative prices of France/Germany could be puzzling. However, the volatility of the residuals of the relative price was already very low around 2004, as Figure 4 shows, and maintained the lowest volatility value for nearly the entire sample period. This result proves that the efficiency in the integration of the German and French markets is only comparable to that reached at the end of the sample by the Italy/Austria pair.

\section{Concluding remarks}

The relative price adjustment in the EMU is a matter of concern for the ECB authorities. In this study, we propose that the hypothesis of price convergence should be evaluated and tested by employing relative prices instead of using the inflation differentials. To this aim, we define a generalized notion of PCM and PCV, provide a model of relative price levels that includes a transition path, and show how to properly test the proposed definitions. This methodology can be used for testing price convergence in any other group of countries or states. Considering the period from 2001 to 2011, we show that the price level trends within the EMU area evolve with different patterns for some countries and that unless these patterns have changed, they do not converge in the long run. 
According to our empirical analysis, within the EMU only the French, Italian, and German price levels converged in mean to a zero-gap. Some others, like Austria/Italy or Germany/Spain, converge in mean to a nonzero significant gap, while not many pairs do so. On the other hand, only the price levels in Italy and Austria seem to converge in variance. However, France and Germany maintained the lowest variance during most of the period, which could mean that the variance already converged to a certain minimum EMU level.

These results and methodology might be considered by policymakers to evaluate the extent to which monetary policy does not affect all EMU members equally. The consequences of reported results for EMU countries could be important in terms of both economic growth and inflation dynamics. Our results also suggest that a central bank's optimal policy framework should include a criterion for price level convergence patterns in the long run (speed of convergence), at least in a relative sense. The methodological framework that we propose may be of great use to policymakers in order to measure, track and forecast price convergence in the Eurozone.

Finally, this study offers a view of the joint cross-country price dynamics before the introduction of liquidity provision programs in the Eurosystem, an intended starting point for a second analysis that includes the post-2011 period and draws a conclusion about the potential effects of liquidity provision programs on the EMU price indices' dynamics and convergence. A future research article, currently in progress, addresses this question. 


\section{References}

Adam, K. and Weber, H. (2019). Optimal trend inflation. American Economic Review, 109(2):702-37.

Alvarez, F. and Dixit, A. (2014). A real options perspective on the future of the euro. Journal of Monetary Economics, 61:78-109.

Andrade, P., Galí, J., Bihan, H. L., and Matheron, J. (2018). The optimal inflation target and the natural rate of interest. Working Paper 24328, National Bureau of Economic Research.

Berk, J. M. and Swank, J. (2002). Regional Price Adjustment in a Monetary Union. Tinbergen Institute Discussion Papers 02-077/2, Tinbergen Institute.

Berka, M., Devereux, M. B., and Engel, C. (2018). Real exchange rates and sectoral productivity in the eurozone. American Economic Review, 6:1543-1581.

Bernard, A. B. and Durlauf, S. N. (1995). Convergence in international output. Journal of Applied Econometrics, 10:97-108.

Bernard, A. B. and Durlauf, S. N. (1996). Interpreting tests of the convergence hypothesis. Journal of Econometrics, 71:161-173.

Beveridge, S. and Nelson, C. R. (1981). A new approach to decomposition of economic time series into permanent and transitory components with particular attention to measurement of the 'business cycle'. Journal of Monetary economics, 7(2):151-174.

Breusch, T. and Pagan, A. (1979). A simple test for heteroscedasticity and random coefficient variation. Econometrica, 47(5):1287-1294.

Bronfenbrenner, M. and Holzman, F. D. (1963). Survey of inflation theory. The American Economic Review, 53(4):pp. 593-661.

Busetti, F., Fabiani, S., and Harvey, A. (2006). Convergence of prices and rates of inflation. Oxford Bulletin of Economics and Statistics, 68:863-877.

Busetti, F., Forni, S., Harvey, A., and Venditti, F. (2007). Inflation convergence and divergence whithin the european monetary union. International Journal of Central Banking, $3(2): 95-121$.

Caballero, R. J., Farhi, E., and Gourinchas, P.-O. (2015). Global Imbalances and Currency Wars at the ZLB. NBER Working Papers 21670, National Bureau of Economic Research, Inc.

Carlsson, M. and Westermark, A. (2016). Labor market frictions and optimal steady-state inflation. Journal of Monetary Economics, 78:67 - 79.

Cecchetti, S. G., Mark, N. C., and Sonora, R. J. (2002). Price index convergence among United States cities. International Economic Review, 43(4):1081-1099.

Chiu, J. and Molico, M. (2010). Liquidity, redistribution, and the welfare cost of inflation. Journal of Monetary Economics, 57(4):428 - 438. 
Cogley, T., Primiceri, G. E., and Sargent, T. J. (2010). Inflation-gap persistence in the us. American Economic Journal: Macroeconomics, 2(1):43-69.

Cogley, T. and Sbordone, A. M. (2008). Trend inflation, indexation, and inflation persistence in the new keynesian phillips curve. American Economic Review, 98(5):2101-26.

de Andoain, C. G., Heider, F., Hoerova, M., and Manganelli, S. (2016). Lending-of-last-resort is as lending-of-last-resort does: Central bank liquidity provision and interbank market functioning in the euro area . ECB working paper, (1886):1-61.

Dornbusch, R. (1987). Purchasing power parity. In Eatwell, J., Milgate, M., and Newman, P., editors, New Palgrave Dictionary of Economics, volume 3. Macmillan.

Draghi, M. (2014). Stability and prosperity in monetary union. Speech by Mario Draghi President of the European Central Bank, at the University of Helsinki, Helsinki, 27 November 2014 .

Duisenberg, W. F. (2000). Are different price developments in the euro area cause of concern. Speech by Dr. William F. Duisemberg President of the European Central Bank, at the Financial Services Industry Association, Dublin, 6 September 2000.

Durlauf, S. N. and Quah, D. T. (1999). The new empirics of economic growth. In Taylor, J. B. and Woodford, M., editors, Handbook of Macroeconomics, volume 1 of Handbook of Macroeconomics, chapter 4, pages 235-308. Elsevier.

Dvir, E. and Strasser, G. (2018). Does marketing widen borders? cross-country price dispersion in the european car market. Journal of International Economics, 112(C):134-149.

Engel, C. and Rogers, J. H. (2004). European product market integration after the euro. Economic Policy, 19(39):347-384.

Erosa, A. and Ventura, G. (2002). On inflation as a regressive consumption tax. Journal of Monetary Economics, 49(4):761 - 795.

Farhi, E. and Maggiori, M. (2017). A Model of the International Monetary System*. The Quarterly Journal of Economics, 133(1):295-355.

Friedman, M. (1963). Inflation: Causes and Consequences. Council for Economic Education (Bombay: Asia Publishing House, 1963), reprinted in Dollars and and Deficits (Englewood CLiffs, N.J.: Prentice-Hall, 1968), pp. 21-71.

Hatcher, M. and Minford, P. (2014). Inflation targeting vs price-level targeting: a new survey of theory and empirics.

Ireland, P. N. (2007). Changes in the federal reserve's inflation target: causes and consequences. Journal of Money, Credit and Banking, 39(8):1851-1882.

Lagos, R. and Wright, R. (2005). A unified framework for monetary theory and policy analysis. Journal of Political Economy, 113(3):463-484.

Laidler, D. E. W. and Parkin, J. M. (1975). Inflation: A survey. Economic Journal, 85(340):741-809. 
Lepetit, A. (2018). The Optimal Inflation Rate with Discount Factor Heterogeneity. Finance and Economics Discussion Series 2018-086, Board of Governors of the Federal Reserve System (US).

Liu, E., Mian, A., and Sufi, A. (2019). Low interest rates, market power, and productivity growth. Working Paper 25505, National Bureau of Economic Research.

Ljung, G. M. and Box, G. E. P. (1978). On a measure of lack of fit in time series models. Biometrika, 65:297-303.

Lopez, C. and Papell, D. H. (2012). Convergence of euro area inflation rates. Journal of International Money and Finance, 31(6):1440-1458.

Lucas, R. E. (2000). Inflation and welfare. Econometrica, 68(2):247-274.

Ogrokhina, O. (2019). Persistence of prices in the eurozone capital cities: Evidence from the economist intelligence unit city data. Economic Modelling, 76(C):330-338.

Quint, D. and Tristani, O. (2017). Liquidity provision as a monetary policy tool: the ECB's non-standard measures after the financial crisis. ECB working paper, (2113):1-48.

Rogers, J. H. (2007). Monetary union, price level convergence, and inflation: How close is Europe to the USA? Journal of Monetary Economics, 54(3):785-796.

Saikkonen, P. and Lutkepohl, H. (2002). Testing for a unit root in a time series with a level shift at unknown time. Econometric Theory, 18:313-348.

Schmitt-Grohé, S. and Uribe, M. (2010). The Optimal Rate of Inflation. In Friedman, B. M. and Woodford, M., editors, Handbook of Monetary Economics, volume 3 of Handbook of Monetary Economics, chapter 13, pages 653-722. Elsevier.

Shin, D. and Fuller, W. (1998). Unit-root tests based on unconditional maximum likelihood estimation for the autoregressive moving average. Journal of Time Series Analysis, 19:591599 .

Sondermann, D. (2014). Productivity in the euro area: any evidence of convergence? Empirical Economics, 47(3):999-1027.

Stock, J. H. and Watson, M. W. (2007). Why Has U.S. Inflation Become Harder to Forecast? Journal of Money, Credit and Banking, 39(s1):3-33.

Sturm, J.-E., Fritsche, U., Lamla, M., Lein, S., Nitsch, V., Liechti, D., and Triet, D. (2009). The euro and prices: changeover-related inflation and price convergence in the euro area. Economic Papers. Economic and Financial Affairs, (381). 
Table 1: Estimated univariate price models

(Quartely Prices in Log Differences)

\begin{tabular}{|c|c|c|c|c|c|c|c|c|}
\hline \multirow{2}{*}{$\begin{array}{c}\text { Variable } \\
\text { (Mnemonics) }\end{array}$} & \multirow{2}{*}{$\begin{array}{c}\mathrm{AR}(1) \\
\hat{\phi}_{11} \\
\text { (s.e.) }\end{array}$} & \multicolumn{2}{|c|}{$\overline{\mathrm{AR}(2)}$} & \multirow{2}{*}{$\begin{array}{c}\text { Mean } \\
(\text { s.e.) } \\
(\%)\end{array}$} & \multirow{2}{*}{$\begin{array}{c}\text { Resid. } \\
\text { Std.Dev. } \\
(\%)\end{array}$} & \multirow{2}{*}{$\begin{array}{c}\mathrm{ACF}^{(1)} \\
Q_{(9)}\end{array}$} & \multirow{2}{*}{$\begin{array}{c}\mathrm{SF}^{(2)} \\
H_{0}: \phi_{1} 1=1\end{array}$} & \multirow{2}{*}{$\begin{array}{c}\mathrm{GLR}^{(3)} \\
H_{0}: \theta=1\end{array}$} \\
\hline & & $\begin{array}{c}\hat{\phi}_{12} \\
\text { (s.e.) }\end{array}$ & $\begin{array}{l}\hat{\phi}_{12} \\
\text { (s.e) }\end{array}$ & & & & & \\
\hline $\begin{array}{l}\text { Austria } \\
\text { (A) }\end{array}$ & $\begin{array}{c}0.26 \\
(0.14)\end{array}$ & - & - & $\begin{array}{c}0.50 \\
(0.07)\end{array}$ & 0.35 & 14.8 & $14.8^{* *}$ & 0.0 \\
\hline $\begin{array}{l}\text { Belgium } \\
\qquad(B)\end{array}$ & $\begin{array}{c}0.43 \\
(0.14)\end{array}$ & - & - & $\begin{array}{c}0.53 \\
(0.11)\end{array}$ & 0.42 & 14.5 & $11.5^{* *}$ & 0.0 \\
\hline $\begin{array}{l}\text { Findland } \\
\qquad(F I)\end{array}$ & $\begin{array}{c}0.38 \\
(0.14)\end{array}$ & - & - & $\begin{array}{c}0.43 \\
(0.10)\end{array}$ & 0.38 & 16.7 & $11.7^{* *}$ & 0.2 \\
\hline $\begin{array}{c}\text { France } \\
(F R)\end{array}$ & $\begin{array}{c}0.31 \\
(0.14)\end{array}$ & - & - & $\begin{array}{c}0.48 \\
(0.07)\end{array}$ & 0.31 & 16.4 & $14.6^{* *}$ & 0.0 \\
\hline $\begin{array}{l}\text { Germany } \\
(G)\end{array}$ & $\begin{array}{c}0.24 \\
(0.15)\end{array}$ & - & - & $\begin{array}{c}0.43 \\
(0.06)\end{array}$ & 0.31 & 8.3 & $17.2^{* *}$ & 0.0 \\
\hline $\begin{array}{l}\text { Greece } \\
(G R)\end{array}$ & $\begin{array}{c}0.34 \\
(0.14)\end{array}$ & - & - & $\begin{array}{c}0.76 \\
(0.10)\end{array}$ & 0.45 & 15.3 & $13.2^{* *}$ & 0.0 \\
\hline $\begin{array}{l}\text { Italy } \\
(I)\end{array}$ & $\begin{array}{c}0.44 \\
(0.20)\end{array}$ & $\begin{array}{l}-0.47 \\
(0.20)\end{array}$ & $\begin{array}{c}0.41 \\
(0.18)\end{array}$ & $\begin{array}{c}0.59 \\
(0.08)\end{array}$ & 0.32 & 11.7 & $7.7^{* *}$ & 0.0 \\
\hline $\begin{array}{l}\text { Ireland } \\
\qquad(I)\end{array}$ & $\begin{array}{c}0.73 \\
(0.10)\end{array}$ & - & - & $\begin{array}{c}0.52 \\
(0.21)\end{array}$ & 0.39 & 18.6 & $2.2^{* *}$ & 0.2 \\
\hline $\begin{array}{l}\text { Netherlands } \\
\qquad(N)\end{array}$ & - & $\begin{array}{c}0.54 \\
(0.16)\end{array}$ & $\begin{array}{l}-0.67 \\
(0.13)\end{array}$ & $\begin{array}{c}0.48 \\
(0.07)\end{array}$ & 0.34 & 15.1 & $5.8^{* *}$ & 0.0 \\
\hline $\begin{array}{l}\text { Portugal } \\
\quad(P)\end{array}$ & $\begin{array}{c}0.38 \\
(0.18)\end{array}$ & - & - & $\begin{array}{c}0.58 \\
(0.11)\end{array}$ & 0.58 & 5.3 & $12.8^{* *}$ & 0.0 \\
\hline $\begin{array}{l}\text { Spain } \\
(S)\end{array}$ & $\begin{array}{c}0.35 \\
(0.15)\end{array}$ & - & - & $\begin{array}{c}0.71 \\
(0.10)\end{array}$ & 0.45 & 6.8 & $13.4^{* *}$ & 0.1 \\
\hline
\end{tabular}

Notes: (1) Q is the Ljung and Box (1978) statistic for the autocorrelation function (ACF). $\mathrm{H}_{0}$ is that there is no autocorrelation in the first nine lags. (2) SF: Shin and Fuller (1998) statistic tests whether an $\operatorname{AR}(1)$ operator is nonstationary. We estimate an alternative ARIMA(3,0,1) model and test the null hypothesis. (3) GLR: Generalized Likelihood Ratio (GLR) test of Davis, Chen and Duismuir (1995) for the null hypothesis of noninvertibility of an MA(1) operator, if a second difference and a MA(1) operator to control over-differentiation are added

${ }^{*}$ Rejects the null hypothesis at the $10 \%$ level, ${ }^{* *}$ Rejects the null hypothesis at the $5 \%$ level. 
Table 2: Relative prices models with convergence path

\begin{tabular}{|c|c|c|c|c|c|c|c|c|c|c|c|}
\hline \multirow[t]{2}{*}{ Sample } & \multirow{2}{*}{$\begin{array}{c}\text { Variable } \\
\text { (Mnemonics) }\end{array}$} & \multirow{2}{*}{$\begin{array}{c}\operatorname{AR}(1) \\
\hat{\phi}_{1} \\
\text { (s.e.) }\end{array}$} & $\operatorname{AR}(2)$ & \multicolumn{4}{|c|}{ Convergence Paramenters } & \multirow{2}{*}{$\begin{array}{c}\text { Mean } \\
\hat{\mu} \\
\text { (s.e.) }\end{array}$} & \multirow{2}{*}{\multicolumn{2}{|c|}{$\begin{array}{cc}\text { Resid. } & \mathrm{ACF}^{(1)} \\
\text { Std.Dev. } & Q_{(9)}\end{array}$}} & \multirow{2}{*}{$\begin{array}{c}\mathrm{SF}^{(2)} \\
H_{0}: \phi=1\end{array}$} \\
\hline & & & $\begin{array}{cc}\hat{\phi}_{21} & \hat{\phi}_{22} \\
\text { (s.e.) } & \text { (s.e.) }\end{array}$ & $\begin{array}{c}\hat{\omega}_{0} \\
\text { (s.e.) }\end{array}$ & $\begin{array}{c}\hat{\delta}_{1} \\
\text { (s.e) }\end{array}$ & $\begin{array}{c}\hat{l} \\
\text { (s.e) }\end{array}$ & $\begin{array}{c}\hat{g} \\
(\mathrm{s.e})\end{array}$ & & & & \\
\hline
\end{tabular}

Panel A: Relative price levels with Germany as Numerarie

\begin{tabular}{|c|c|c|c|c|c|c|c|c|c|c|c|c|}
\hline \multirow[t]{10}{*}{$\overline{2001 / I V}$} & Austria & $\begin{array}{c}0.98 \\
(0.03)\end{array}$ & - & - & $\begin{array}{l}-0.0051 \\
(0.0026)\end{array}$ & $\begin{array}{l}-0.33 \\
(0.34)\end{array}$ & - & - & $\begin{array}{c}-0.18 \\
(1.08)\end{array}$ & 0.26 & $16.6^{* *}$ & 0.0 \\
\hline & Belgium & $\begin{array}{c}0.95 \\
(0.07)\end{array}$ & $\begin{array}{c}0.57 \\
(0.17)\end{array}$ & - & $\begin{array}{l}-0.0040 \\
(0.0029)\end{array}$ & $\begin{array}{c}0.17 \\
(0.42)\end{array}$ & - & - & $\begin{array}{l}-0.73 \\
(0.24)\end{array}$ & 0.27 & $13.4^{* *}$ & 0.0 \\
\hline & Findland & $\begin{array}{c}0.98 \\
(0.02)\end{array}$ & - & - & $\begin{array}{l}-0.0046 \\
(0.0022)\end{array}$ & $\begin{array}{l}-0.91 \\
(0.12)\end{array}$ & - & - & $\begin{array}{l}16.7 \\
(0.3)\end{array}$ & 0.31 & 26.9 & 0.0 \\
\hline & France & $\begin{array}{c}0.77 \\
(0.10)\end{array}$ & - & - & $\begin{array}{c}0.0030 \\
(0.0010)\end{array}$ & $\begin{array}{c}0.86 \\
(0.04)\end{array}$ & $\begin{array}{c}5.9 \\
(2.1)\end{array}$ & $\begin{array}{l}2.0 \\
(0.4)\end{array}$ & $\begin{array}{l}-2.1 \\
(0.3)\end{array}$ & 0.19 & $18.9^{* *}$ & $1.8^{* *}$ \\
\hline & Greece & $\begin{array}{c}0.52 \\
(0.25)\end{array}$ & $\begin{array}{c}0.52 \\
(0.25)\end{array}$ & - & $\begin{array}{c}0.0069 \\
(0.0007)\end{array}$ & $\begin{array}{c}1.00 \\
(0.01)\end{array}$ & - & - & $\begin{array}{l}-26.3 \\
(1.7)\end{array}$ & 0.38 & $12.1^{* *}$ & $4.7^{* *}$ \\
\hline & Ireland & $\begin{array}{c}0.89 \\
(0.09)\end{array}$ & $\begin{array}{c}0.28 \\
(0.15)\end{array}$ & $\begin{array}{c}0.54 \\
(0.14)\end{array}$ & $\begin{array}{c}0.0071 \\
(0.0086)\end{array}$ & $\begin{array}{c}0.86 \\
(0.08)\end{array}$ & - & - & $\begin{array}{l}10.2 \\
(2.5)\end{array}$ & 0.31 & $11.8^{* *}$ & 0.4 \\
\hline & Italy & $\begin{array}{c}0.70 \\
(0.20)\end{array}$ & $\begin{array}{l}-0.11 \\
(0.21)\end{array}$ & $\begin{array}{c}0.57 \\
(0.19)\end{array}$ & $\begin{array}{c}0.0026 \\
(0.0009)\end{array}$ & $\begin{array}{c}0.96 \\
(0.02)\end{array}$ & $\begin{array}{c}25.0 \\
(15.4)\end{array}$ & $\begin{array}{l}6.9 \\
(2.0)\end{array}$ & $\begin{array}{l}-6.6 \\
(0.5)\end{array}$ & 0.25 & $4.5^{* *}$ & $1.8^{* *}$ \\
\hline & Netherlands & $\begin{array}{c}0.90 \\
(0.07)\end{array}$ & - & - & $\begin{array}{c}0.0063 \\
(0.0023)\end{array}$ & $\begin{array}{c}0.67 \\
(0.12)\end{array}$ & - & - & $\begin{array}{l}-3.2 \\
(0.6)\end{array}$ & 0.29 & $11.2^{* *}$ & 0.0 \\
\hline & Portugal & $\begin{array}{c}0.78 \\
(0.10)\end{array}$ & - & - & $\begin{array}{c}0.0071 \\
(0.0016)\end{array}$ & $\begin{array}{c}0.87 \\
(0.03)\end{array}$ & $\begin{array}{c}6.9 \\
(1.8)\end{array}$ & $\begin{array}{c}5.6 \\
(0.6)\end{array}$ & $\begin{array}{l}-23.5 \\
(0.5)\end{array}$ & 0.33 & $12.1^{* *}$ & $1.8^{* *}$ \\
\hline & Spain & $\begin{array}{c}0.68 \\
(0.11)\end{array}$ & - & - & $\begin{array}{c}0.0063 \\
(0.0005)\end{array}$ & $\begin{array}{c}0.95 \\
(0.01)\end{array}$ & $\begin{array}{l}18.8 \\
(2.3)\end{array}$ & $\begin{array}{l}12.5 \\
(0.6)\end{array}$ & $\begin{array}{r}-22.6 \\
(0.3)\end{array}$ & 0.24 & $20.2^{* *}$ & $4.1^{* *}$ \\
\hline
\end{tabular}

Notes: (1) Q is the Ljung and Box (1978) statistic for the autocorrelation function (ACF). $\mathrm{H}_{0}$ is that there is no autocorrelation in the first nine lags. (2) SF: Shin and Fuller (1998) statistic tests whether an AR(1) operator is nonstationary. ${ }^{*}$ Rejects the null hypothesis at the $10 \%$ level, ${ }^{* *}$ Rejects the null hypothesis at the $5 \%$ level. 
Table 3: Testing Relative Asymptotic Price Convergence in Mean by Pairs

Panel A: SF Unit Root test for convergence in mean ${ }^{1}$

\begin{tabular}{|c|lllllllllll|}
\hline Country & Germany & Austria & Belgium & Findland & France & Greece & Ireland & Italy & Netherlands & Portugal & Spain \\
\hline & & & & & & & & & & & \\
Germany & $\mathrm{X}$ & 0.0 & 0.0 & 0.0 & $1.8^{* *}$ & $4.7^{* *}$ & 0.4 & $1.8^{* *}$ & 0.0 & $1.8^{* *}$ & $4.1^{* *}$ \\
Austria & 0.0 & $\mathrm{X}$ & $5.5^{* *}$ & 0.0 & 0.3 & $2.2^{* *}$ & 0.4 & $3.8^{* *}$ & 0.0 & 0.0 & $2.0^{* *}$ \\
Belgium & 0.0 & $5.5^{* *}$ & $\mathrm{X}$ & 0.1 & 0.0 & $2.5^{* *}$ & 0.0 & $1.3^{*}$ & 0.0 & 0.0 & 0.0 \\
Findland & 0.0 & 0.0 & 0.1 & $\mathrm{X}$ & 0.0 & 0.5 & 0.0 & 0.0 & 0.0 & 0.3 & 0.0 \\
France & $1.8^{* *}$ & 0.3 & 0.0 & 0.0 & $\mathrm{X}$ & $4.8^{* *}$ & 0.1 & $2.6^{* *}$ & $2.9^{* *}$ & $2.7^{* *}$ & $1.5^{*}$ \\
Greece & $4.7^{* *}$ & $2.2^{* *}$ & $2.5^{* *}$ & 0.5 & $4.8^{* *}$ & $\mathrm{X}$ & $2.5^{* *}$ & $4.1^{* *}$ & $4.8^{* *}$ & 0.8 & $1.3^{*}$ \\
Ireland & 0.4 & 0.4 & 0.1 & 0.0 & 0.1 & $2.5^{* *}$ & $\mathrm{X}$ & 0.0 & 0.0 & 0.0 & 0.0 \\
Italy & $1.8^{* *}$ & $3.8^{* *}$ & $1.3^{*}$ & 0.0 & $2.6^{* *}$ & $4.1^{* *}$ & 0.0 & $\mathrm{X}$ & $9.5^{* *}$ & 0.9 & $2.0^{* *}$ \\
Neetherlands & 0.0 & 0.0 & 0.0 & 0.0 & $2.9^{* *}$ & $4.8^{* *}$ & 0.0 & $9.5^{* *}$ & $\mathrm{X}$ & $1.4^{*}$ & $3.8^{* *}$ \\
Portugal & $1.8^{* *}$ & 0.0 & 0.0 & 0.3 & $2.7^{* *}$ & 0.8 & 0.0 & 0.9 & $1.4^{*}$ & $\mathrm{X}$ & $1.9^{* *}$ \\
Spain & $4.1^{* *}$ & $2.0^{* *}$ & 0.0 & 0.0 & $1.5^{*}$ & $1.3^{*}$ & 0.0 & $2.0^{* *}$ & $3.8^{* *}$ & $1.9^{* *}$ & $\mathrm{X}$ \\
\hline
\end{tabular}

Panel B: Stability t-student Test for the Convergence Operator ${ }^{2}$

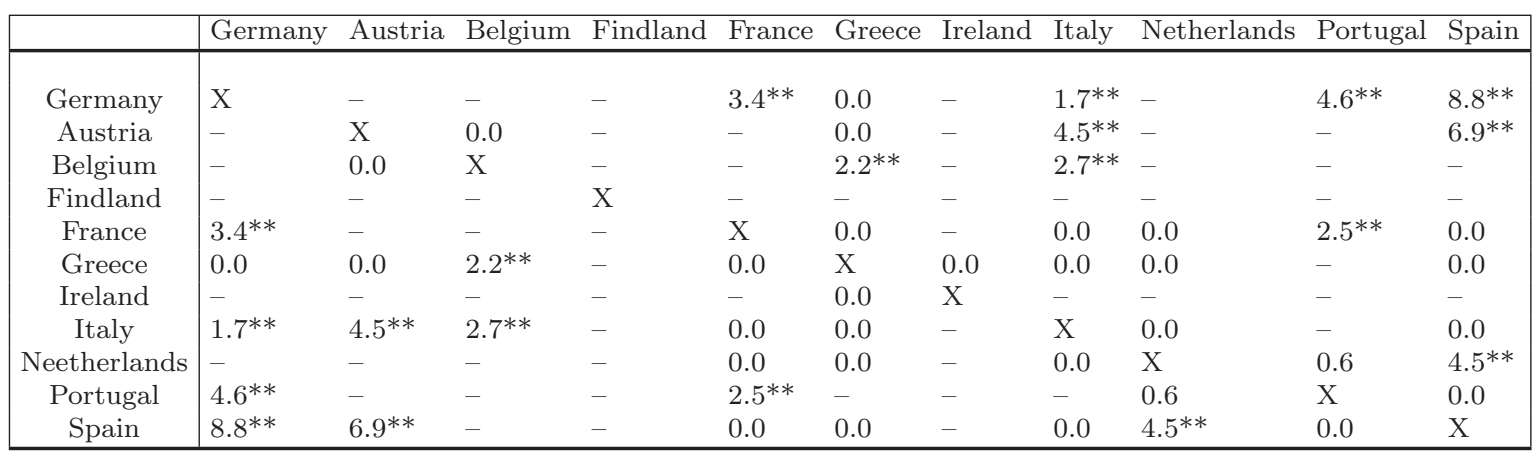

Notes: (1) SF: Shin and Fuller (1998) statistic tests whether an $\operatorname{AR}(1)$ operator is nonstationary, where $H_{0}: \phi=1$, i.e. the $\operatorname{AR}(1)$ has a unit root. (2) Stability t-student Test for the convergence operator, $\nu_{i j}(B)$, where $\mathrm{H}_{0}: \delta=1$. If the null hypothesis cannot be reject, there is evidence of a positive or negative ramp depending of the sign of $\nu_{i j}(B)$. For instance $g$ is not finite. $\left.{ }^{*}{ }^{* *}\right)$ Rejects the null hypothesis at the $10 \%(5 \%)$ level. 
Table 4: Testing Absolute Asymptotic Price Convergence in Mean and Speed Significance by Pairs

Panel A: Long Run Gap Estimation Results and t-student test for convergence in mean ${ }^{1}$

\begin{tabular}{|c|c|c|c|c|c|c|c|c|c|c|c|}
\hline Country & Germany & Austria & Belgium & Findland & France & Greece & Ireland & Italy & Netherlands & Portugal & Spain \\
\hline Germany & $\mathrm{X}$ & - & - & - & -0.001 & - & - & -0.3 & - & $-17.4^{* *}$ & $-10.1^{* *}$ \\
\hline Austria & - & $\mathrm{X}$ & - & - & - & - & - & $-1.2^{* *}$ & - & - & $-8.3^{* *}$ \\
\hline Belgium & - & - & $\mathrm{X}$ & - & - & $-8.4^{* *}$ & - & $-1.7^{* *}$ & - & - & - \\
\hline Findland & - & - & - & $\mathrm{X}$ & - & - & - & - & - & - & - \\
\hline France & 0.001 & - & - & - & $\mathrm{X}$ & - & - & - & - & $-17.9^{* *}$ & - \\
\hline Greece & - & - & $8.4^{* *}$ & - & - & $\mathrm{X}$ & - & - & - & - & - \\
\hline Ireland & - & - & - & - & - & - & $\mathrm{X}$ & - & - & - & - \\
\hline Italy & 0.3 & $1.2^{* *}$ & $1.7^{* *}$ & - & - & - & - & $\mathrm{X}$ & - & - & - \\
\hline Neetherlands & - & - & - & - & - & - & - & - & $\mathrm{X}$ & - & $-8.9^{* *}$ \\
\hline Portugal & $17.4^{* *}$ & - & - & - & $17.9^{* *}$ & - & - & - & - & $\mathrm{X}$ & - \\
\hline Spain & $10.1^{* *}$ & $8.3^{* *}$ & - & - & - & - & - & - & $8.9^{* *}$ & - & $\mathrm{X}$ \\
\hline
\end{tabular}

Panel B: Convergence Speed Estimation Results and t-student test for significance ${ }^{3}$

\begin{tabular}{|c|c|c|c|c|c|c|c|c|c|c|c|}
\hline Country & Germany & Austria & Belgium & Findland & France & Greece & Ireland & Italy & Netherlands & Portugal & Spain \\
\hline Germany & $\mathrm{X}$ & - & - & - & $5.9^{* *}$ & - & - & $25.0^{*}$ & - & $5.6^{* *}$ & $18.8^{* *}$ \\
\hline Austria & - & $\mathrm{X}$ & - & - & - & - & - & $13.8^{* *}$ & - & - & $27.4^{* *}$ \\
\hline Belgium & - & - & $\mathrm{X}$ & - & - & $33.5^{* *}$ & - & $2.4^{* *}$ & - & - & - \\
\hline Findland & - & - & - & $\mathrm{X}$ & - & - & - & - & - & - & - \\
\hline France & $5.9^{* *}$ & - & - & - & $\mathrm{X}$ & - & - & - & - & $8.3^{* *}$ & - \\
\hline Greece & - & - & $33.5^{* *}$ & - & - & $\mathrm{X}$ & - & - & - & - & - \\
\hline Ireland & - & - & - & - & - & - & $\mathrm{X}$ & - & - & - & - \\
\hline Italy & $25.0^{* *}$ & $13.8^{* *}$ & $2.4^{* *}$ & - & - & - & - & $\mathrm{X}$ & - & - & - \\
\hline Neetherlands & - & - & - & - & - & - & - & - & $\mathrm{X}$ & - & $11.5^{* *}$ \\
\hline Portugal & $5.6^{* *}$ & - & - & - & $8.3^{* *}$ & - & - & - & - & $\mathrm{X}$ & - \\
\hline Spain & $18.8^{* *}$ & $27.4^{* *}$ & - & - & - & - & - & - & $11.5^{* *}$ & - & $\mathrm{X}$ \\
\hline
\end{tabular}

Notes: (1) The Tau test is a student-t test of Asymptotic Price Convergence in Mean, where $\mathrm{H}_{0}: \tau_{i j}=g_{i j}+\mu_{i j}=0$ is that the long run gap between nominal prices is zero. Only the long-run gap estimation is presented when convergence is accepted, otherwise (-) no evidence of convergence was found.

$\left.*^{* *}\right)$ Rejects the null hypothesis at the $10 \%(5 \%)$ level.

Table 5: Testing Asymptotic Price Convergence in Variance by Pairs ${ }^{1}$

\begin{tabular}{|c|cccccccccccc|}
\hline Country & \multicolumn{10}{|c|}{ Germany } & Austria Belgium Findland France Greece Ireland Italy Netherlands Portugal Spain \\
\hline Germany & $\mathrm{X}$ & - & - & - & 1.2 & - & - & 0.5 & - & 1.3 & 2.3 \\
Austria & - & $\mathrm{X}$ & - & - & - & - & - & $5.3^{* *}$ & - & - & 1.3 \\
Belgium & - & - & $\mathrm{X}$ & - & - & 2.3 & - & $9.3^{* *}$ & - & - & - \\
Findland & - & - & - & $\mathrm{X}$ & - & - & - & - & - & - & - \\
France & 1.2 & - & - & - & $\mathrm{X}$ & - & - & - & - & 1.7 & - \\
Greece & - & - & 2.3 & - & - & $\mathrm{X}$ & - & - & - & - & - \\
Ireland & - & - & - & - & - & - & $\mathrm{X}$ & - & - & - & - \\
Italy & 0.5 & $5.3^{* *}$ & $9.3^{* *}$ & - & - & - & - & $\mathrm{X}$ & - & - & - \\
Neetherlands & - & - & - & - & - & - & - & - & $\mathrm{X}$ & - & $3.6^{*}$ \\
Portugal & 1.3 & - & - & - & 1.7 & - & - & - & - & $\mathrm{X}$ & - \\
Spain & 2.3 & 1.3 & - & - & - & - & - & - & $3.6^{*}$ & - & $\mathrm{X}$ \\
\hline
\end{tabular}

Notes: (1) Breusch-Pagan test is a Likelihood Ratio test of Asymptotic Price Convergence in Variance, where $\mathrm{H}_{0}$ is homoscedasticity. If the null hypothesis is rejected, there is conditional heteroscedasticity, with variance decreasing (increasing) with time starting at $t^{*}$.

${ }^{*}(*)$ Rejects the null hypothesis at the $10 \%(5 \%)$ level. 
Figure 2: Price levels in the EMU

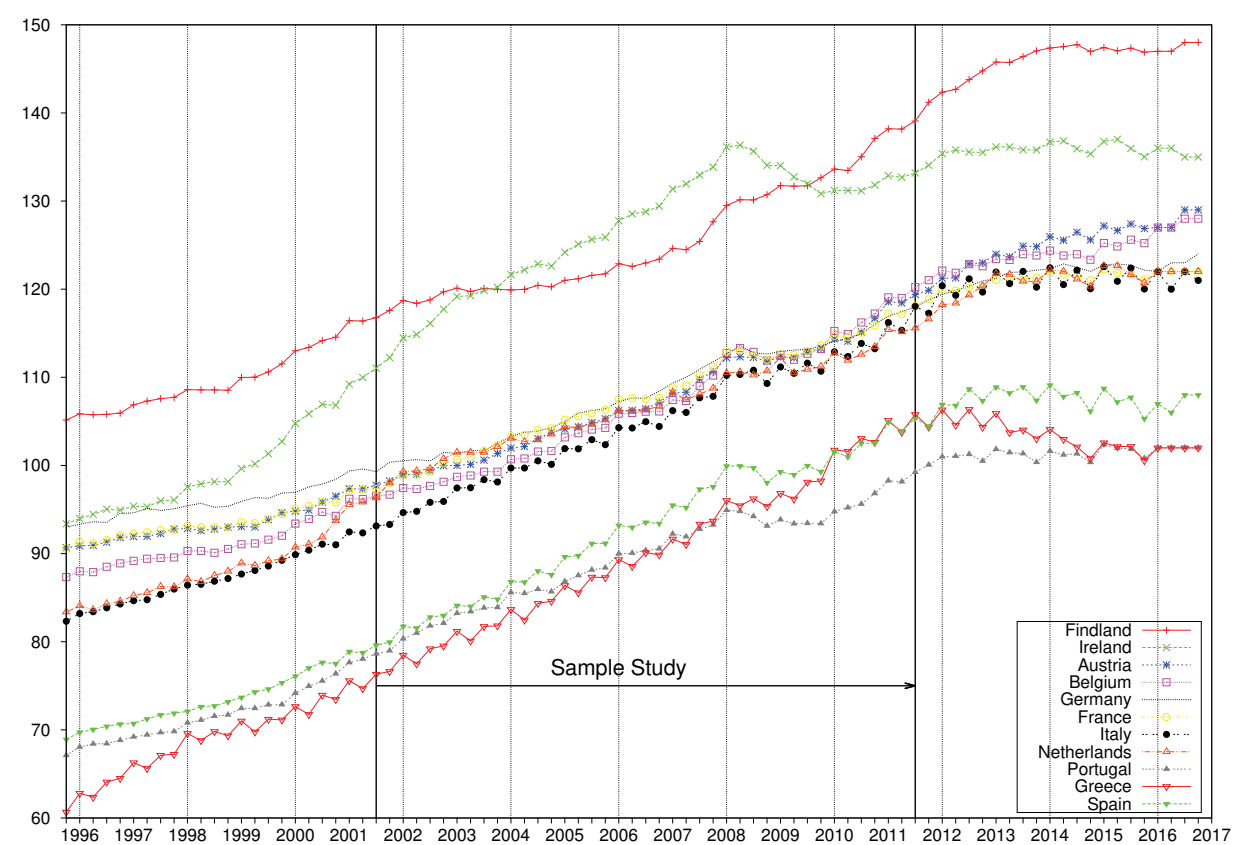


Figure 3: Relative prices in the EMU with Germany as numéraire

A. Relative Price Level France/Germany

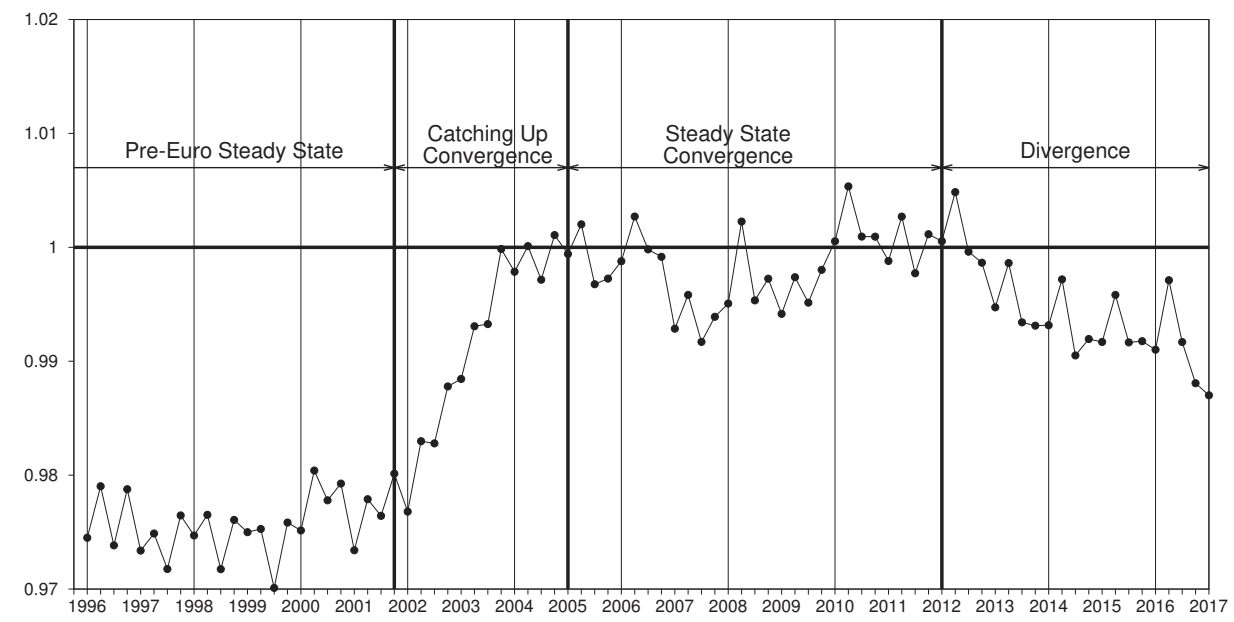

B. Relative Price Level Club B with Germany as Numeraire

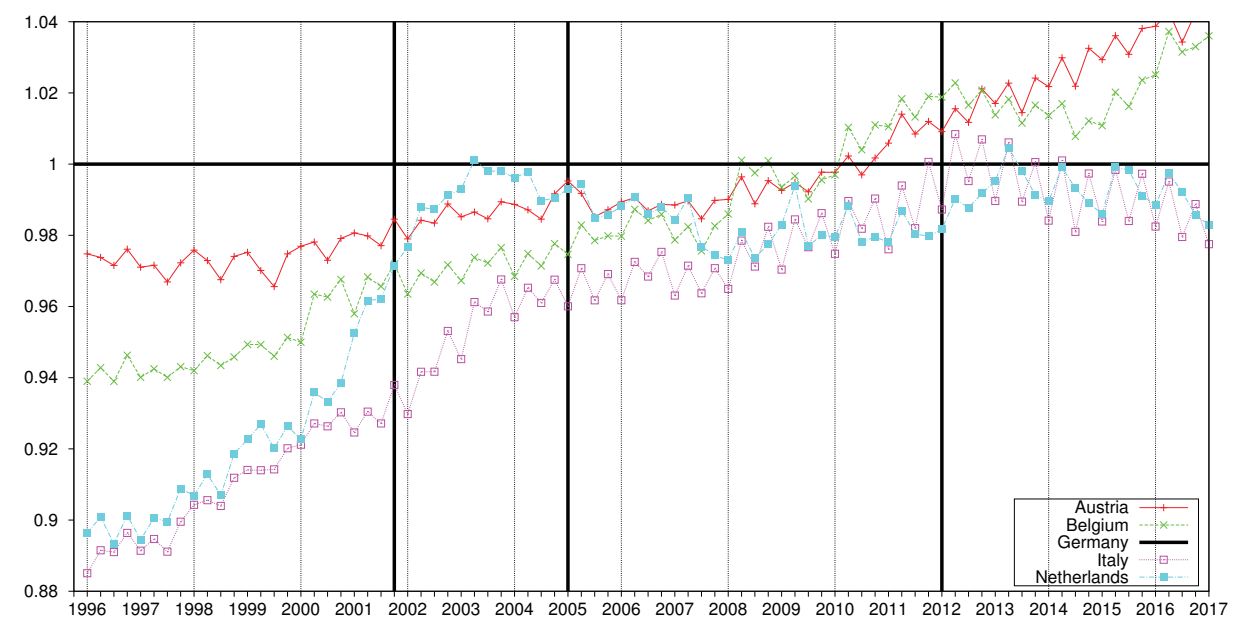

C. Relative Price Level Club C with Germany as Numeraire

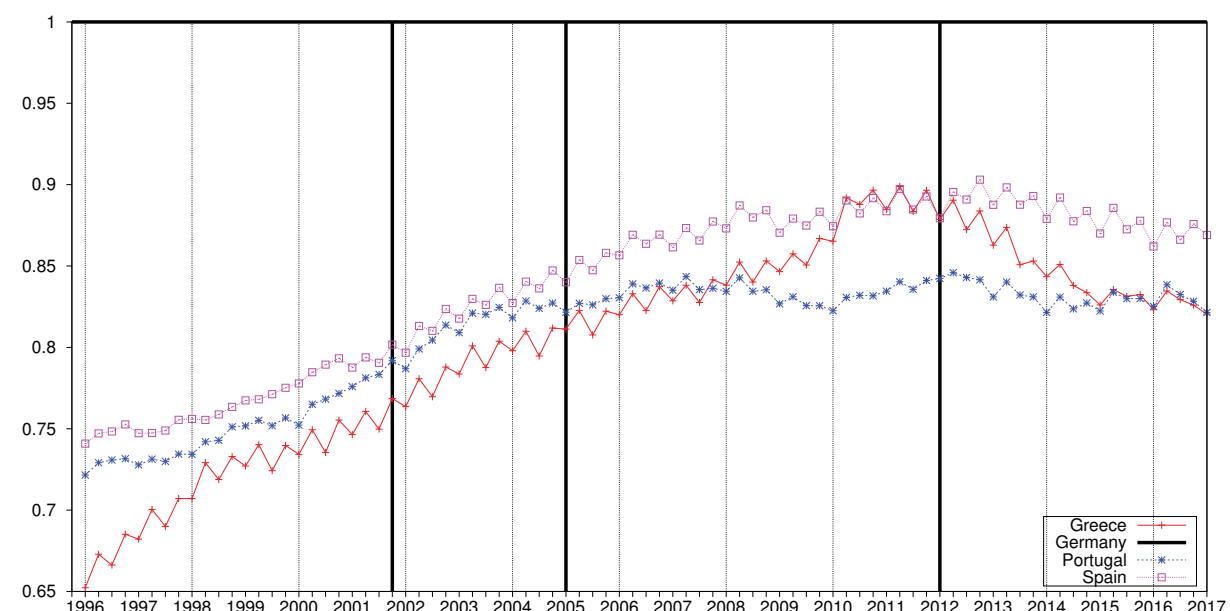


Figure 4: Price Convergence in Variance in the EMU

The series are the residual standard deviations of the natural log of relative prices calculated using rolling windows with a span of $t=25$.

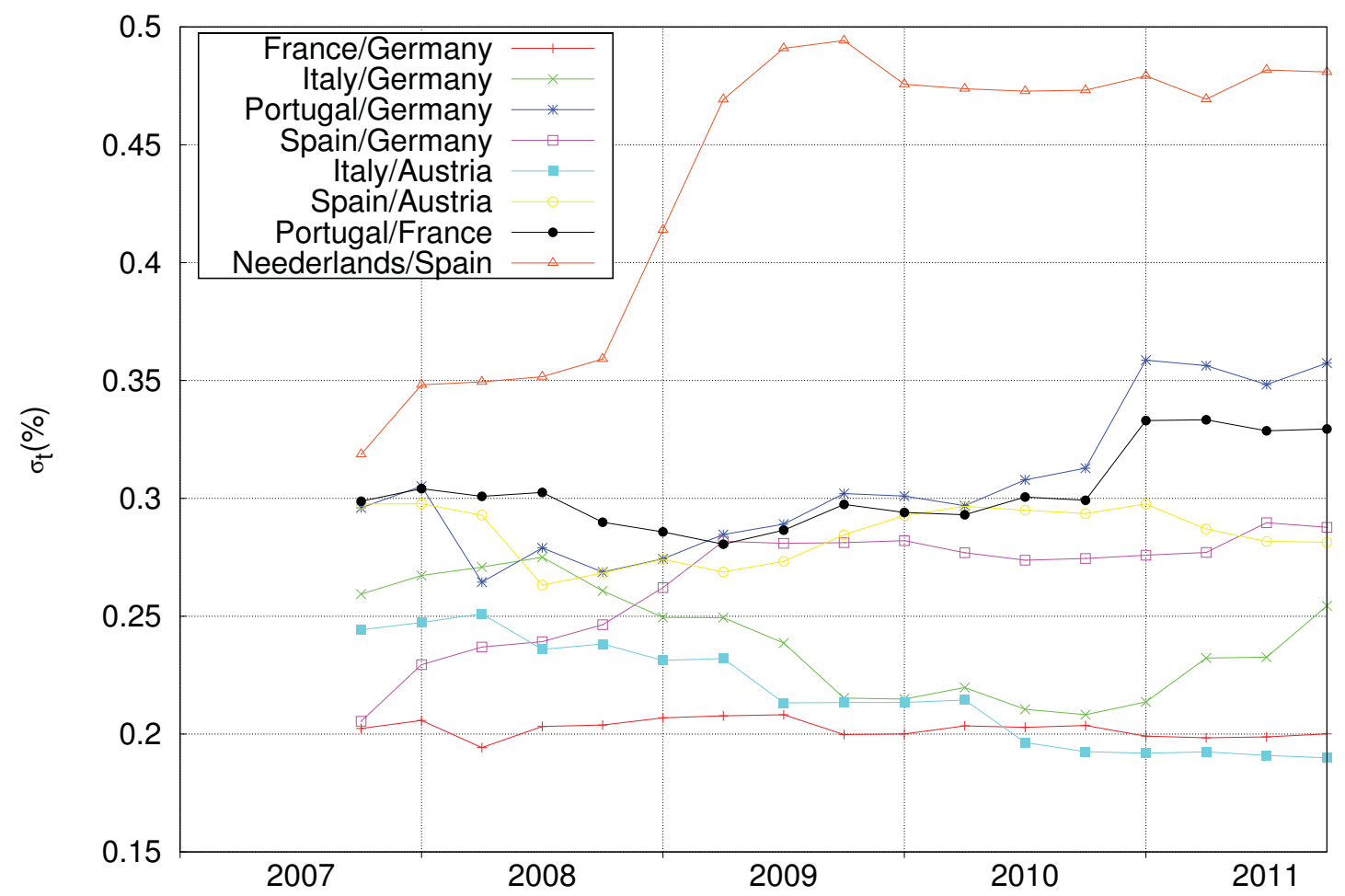




\section{BANCO DE ESPAÑA PUBLICATIONS}

\section{WORKING PAPERS}

1910 JAMES COSTAIN, ANTON NAKOV and BORJA PETIT: Monetary policy implications of state-dependent prices and wages

1911 JAMES CLOYNE, CLODOMIRO FERREIRA, MAREN FROEMEL and PAOLO SURICO: Monetary policy, corporate finance and investment.

1912 CHRISTIAN CASTRO and JORGE E. GALÁN: Drivers of productivity in the Spanish banking sector: recent evidence.

1913 SUSANA PÁRRAGA RODRÍGUEZ: The effects of pension-related policies on household spending.

1914 MÁXIMO CAMACHO, MARÍA DOLORES GADEA and ANA GÓMEZ LOSCOS: A new approach to dating the reference cycle.

1915 LAURA HOSPIDO, LUC LAEVEN and ANA LAMO: The gender promotion gap: evidence from Central Banking.

1916 PABLO AGUILAR, STEPHAN FAHR, EDDIE GERBA and SAMUEL HURTADO: Quest for robust optimal macroprudential policy.

1917 CARMEN BROTO and MATÍAS LAMAS: Is market liquidity less resilient after the financial crisis? Evidence for US treasuries.

1918 LAURA HOSPIDO and CARLOS SANZ: Gender Gaps in the Evaluation of Research: Evidence from Submissions to Economics Conferences.

1919 SAKI BIGIO, GALO NUÑO and JUAN PASSADORE: A framework for debt-maturity management.

1920 LUIS J. ÁLVAREZ, MARÍA DOLORES GADEA and ANA GÓMEZ-LOSCOS: Inflation interdependence in advanced economies.

1921 DIEGO BODAS, JUAN R. GARCÍA LÓPEZ, JUAN MURILLO ARIAS, MATÍAS J. PACCE, TOMASA RODRIGO LÓPEZ, JUAN DE DIOS ROMERO PALOP, PEP RUIZ DE AGUIRRE, CAMILO A. ULLOA and HERIBERT VALERO LAPAZ: Measuring retail trade using card transactional data.

1922 MARIO ALLOZA and CARLOS SANZ: Jobs multipliers: evidence from a large fiscal stimulus in Spain.

1923 KATARZYNA BUDNIK, MASSIMILIANO AFFINITO, GAIA BARBIC, SAIFFEDINE BEN HADJ, ÉDOUARD CHRÉTIEN, HANS DEWACHTER, CLARA ISABEL GONZÁLEZ, JENNY HU, LAURI JANTUNEN, RAMONA JIMBOREAN, OTSO MANNINEN, RICARDO MARTINHO, JAVIER MENCÍA, ELENA MOUSARRI, LAURYNAS NARUŠEVIČIUS, GIULIO NICOLETTI, MICHAEL O'GRADY, SELCUK OZSAHIN, ANA REGINA PEREIRA, JAIRO RIVERA-ROZO, CONSTANTINOS TRIKOUPIS, FABRIZIO VENDITTI and SOFÍA VELASCO: The benefits and costs of adjusting bank capitalisation: evidence from Euro Area countries.

1924 MIGUEL ALMUNIA and DAVID LÓPEZ-RODRÍGUEZ: The elasticity of taxable income in Spain: 1999-2014.

1925 DANILO LEIVA-LEON and LORENZO DUCTOR: Fluctuations in global macro volatility.

1926 JEF BOECKX, MAARTEN DOSSCHE, ALESSANDRO GALESI, BORIS HOFMANN and GERT PEERSMAN: Do SVARs with sign restrictions not identify unconventional monetary policy shocks?

1927 DANIEL DEJUÁN and JUAN S. MORA-SANGUINETTI: Quality of enforcement and investment decisions. Firm-level evidence from Spain.

1928 MARIO IZQUIERDO, ENRIQUE MORAL-BENITO and ELVIRA PRADES: Propagation of sector-specific shocks within Spain and other countries.

1929 MIGUEL CASARES, LUCA DEIDDA and JOSÉ E. GALDÓN-SÁNCHEZ: On financial frictions and firm market power.

1930 MICHAEL FUNKE, DANILO LEIVA-LEON and ANDREW TSANG: Mapping China's time-varying house price landscape.

1931 JORGE E. GALÁN and MATÍAS LAMAS: Beyond the LTV ratio: new macroprudential lessons from Spain.

1932 JACOPO TIMINI: Staying dry on Spanish wine: the rejection of the 1905 Spanish-Italian trade agreement.

1933 TERESA SASTRE and LAURA HERAS RECUERO: Domestic and foreign investment in advanced economies. The role of industry integration.

1934 DANILO LEIVA-LEON, JAIME MARTÍNEZ-MARTÍN and EVA ORTEGA: Exchange rate shocks and inflation comovement in the euro area.

1935 FEDERICO TAGLIATI: Child labor under cash and in-kind transfers: evidence from rural Mexico.

1936 ALBERTO FUERTES: External adjustment with a common currency: the case of the euro area.

1937 LAURA HERAS RECUERO and ROBERTO PASCUAL GONZÁLEZ: Economic growth, institutional quality and financial development in middle-income countries.

1938 SILVIA ALBRIZIO, SANGYUP CHOI, DAVIDE FURCERI and CHANSIK YOON: International Bank Lending Channel of Monetary Policy.

1939 MAR DELGADO-TÉLLEZ, ENRIQUE MORAL-BENITO and JAVIER J. PÉREZ: Outsourcing and public expenditure: an aggregate perspective with regional data. 
1940 MYROSLAV PIDKUYKO: Heterogeneous spillovers of housing credit policy.

1941 LAURA ÁLVAREZ ROMÁN and MIGUEL GARCÍA-POSADA GÓMEZ: Modelling regional housing prices in Spain.

1942 STÉPHANE DÉES and ALESSANDRO GALESI: The Global Financial Cycle and US monetary policy in an interconnected world.

1943 ANDRÉS EROSA and BEATRIZ GONZÁLEZ: Taxation and the life cycle of firms.

1944 MARIO ALLOZA, JESÚS GONZALO and CARLOS SANZ: Dynamic effects of persistent shocks.

1945 PABLO DE ANDRÉS, RICARDO GIMENO and RUTH MATEOS DE CABO: The gender gap in bank credit access.

1946 IRMA ALONSO and LUIS MOLINA: The SHERLOC: an EWS-based index of vulnerability for emerging economies.

1947 GERGELY GANICS, BARBARA ROSSI and TATEVIK SEKHPOSYAN: From Fixed-event to Fixed-horizon Density Forecasts: Obtaining Measures of Multi-horizon Uncertainty from Survey Density Forecasts.

1948 GERGELY GANICS and FLORENS ODENDAHL: Bayesian VAR Forecasts, Survey Information and Structural Change in the Euro Area.

2001 JAVIER ANDRÉS, PABLO BURRIEL and WENYI SHEN: Debt sustainability and fiscal space in a heterogeneous Monetary Union: normal times vs the zero lower bound.

2002 JUAN S. MORA-SANGUINETTI and RICARDO PÉREZ-VALLS: ¿Cómo afecta la complejidad de la regulación a la demografía empresarial? Evidencia para España.

2003 ALEJANDRO BUESA, FRANCISCO JAVIER POBLACIÓN GARCÍA and JAVIER TARANCÓN: Measuring the procyclicality of impairment accounting regimes: a comparison between IFRS 9 and US GAAP.

2004 HENRIQUE S. BASSO and JUAN F. JIMENO: From secular stagnation to robocalypse? Implications of demographic and technological changes.

2005 LEONARDO GAMBACORTA, SERGIO MAYORDOMO and JOSÉ MARÍA SERENA: Dollar borrowing, firm-characteristics, and FX-hedged funding opportunities.

2006 IRMA ALONSO ÁLVAREZ, VIRGINIA DI NINO and FABRIZIO VENDITTI: Strategic interactions and price dynamics in the global oil market.

2007 JORGE E. GALÁN: The benefits are at the tail: uncovering the impact of macroprudential policy on growth-at-risk.

2008 SVEN BLANK, MATHIAS HOFFMANN and MORITZ A. ROTH: Foreign direct investment and the equity home bias puzzle.

2009 AYMAN EL DAHRAWY SÁNCHEZ-ALBORNOZ and JACOPO TIMINI: Trade agreements and Latin American trade (creation and diversion) and welfare.

2010 ALFREDO GARCÍA-HIERNAUX, MARÍA T. GONZÁLEZ-PÉREZ and DAVID E. GUERRERO: Eurozone prices: a tale of convergence and divergence.

BANCODEESPAÑA

Eurosistema
Unidad de Servicios Generales

Alcalá, 48 - 28014 Madrid

E-mail: publicaciones@bde.es www.bde.es 